\title{
An improved cloud index for estimating downwelling surface solar irradiance from various satellite imagers in the framework of a Heliosat-V method
}

\author{
Benoît Tournadre $^{1}$, Benoît Gschwind ${ }^{1}$, Yves-Marie Saint-Drenan ${ }^{1}$, and Philippe Blanc ${ }^{1}$ \\ ${ }^{1}$ MINES ParisTech, PSL Research University, O.I.E. - Centre Observation, Impacts, Energy, 06904 Sophia Antipolis, France \\ Correspondence: Philippe Blanc (philippe.blanc@mines-paristech.fr)
}

\begin{abstract}
We develop a new way to retrieve the cloud index from a large variety of satellite instruments sensitive to reflected solar radiation, embedded on geostationary as non geostationary platforms. The cloud index is a widely used proxy for the effective cloud transmissivity, also called clear-sky index. This study is in the framework of the development of the Heliosat$\mathrm{V}$ method for estimating downwelling solar irradiance at the surface of the Earth (DSSI) from satellite imagery. To reach

5 its versatility, the method uses simulations from a fast radiative transfer model to estimate overcast (cloudy) and clear-sky (cloud-free) satellite scenes of the Earth's reflectances. Simulations consider the anisotropy of the reflectances caused by both surface and atmosphere, and are adapted to the spectral sensitivity of the sensor. The anisotropy of ground reflectances is described by a bidirectional reflectance distribution function model and external satellite-derived data. An implementation of the method is applied to the visible imagery from a Meteosat Second Generation satellite, for 11 locations where high quality in situ measurements of DSSI are available from the Baseline Surface Radiation Network. Results from our preliminary implementation of Heliosat- $\mathrm{V}$ and ground-based measurements show a correlation coefficient reaching 0.948, for 15-minute means of DSSI, similar to operational and corrected satellite-based data products ( 0.950 for HelioClim 3 version 5 and 0.937 for CAMS Radiation Service).
\end{abstract}

\section{Introduction}

Downwelling surface solar irradiance (DSSI) is one of the Essential Climate Variables defined by the Global Climate Observing System (GCOS, 2016). It is the solar part of the downwelling irradiance at the surface of the Earth and on an horizontal unit surface. The solar irradiance is defined as the integration on the spectral interval 290-3000 nm, accordingly to WMO (2014). DSSI considers the irradiance coming from all directions of the hemisphere above the surface: the irradiance coming from the direction of the Sun, plus a diffuse component due to scattering caused by the atmosphere (clouds, gases, aerosols) and reflection by the surface.

The knowledge of DSSI variations in space and time is of primary importance for various fields such as Earth sciences, renewable solar energy industries, agriculture, or some medical fields. To meet all these needs, an ideal information on DSSI would feature high spatio-temporal resolution, a coverage of the entire Earth's surface, and the longest time period possible. 
Long time series of data are notably useful to identify statistics of long-term inter-annual to multi-decadal variability and possible trends, if bias and standard deviation of the error requirements are reached.

Different approaches already exist to produce such DSSI data. Sources of data mainly include ground pyranometric measurements, e.g. from national meteorological and hydrological services, numerical weather prediction (NWP) modeling, e.g. the Modern-Era Retrospective Analysis for Research and Applications, version 2 (MERRA-2) (Gelaro et al., 2017) and the European Centre for Medium-range Weather Forecasts (ECMWF) reanalyses ERA-5 (Hersbach et al., 2020), and satellite-based remote sensing, e.g. methods listed by Sengupta et al. (2017). Satellite-based methods are an efficient and accurate way to produce kilometric and sub-hourly resolved multidecadal time series of DSSI. A more comprehensive review of pros and cons of different approaches is notably described in Huang et al. (2019).

The imagery produced by satellite radiometers provides a unique perspective on DSSI. Upwelling radiances coming from each location on Earth are acquired several times per day by a wide set of satellite imagers. This can particularly be achieved thanks to imagers embedded on meteorological geostationary (GEOs) and polar orbiting satellites like the Polar Operational Environmental Satellites (POES) from the National Oceanic and Atmospheric Administration (NOAA), and the MetOp series operated by the European Organisation for the Exploitation of Meteorological Satellites (EUMETSAT). Another approach exists since 2015, thanks to the Deep Space Climate Observatory (DSCOVR) satellite mission: its Lissajous orbit around the L1 Lagrangian point between the Earth and the Sun makes it possible to picture the whole sunlit hemisphere of the planet, with a single satellite radiometer (Marshak et al., 2018; Hao et al., 2020).

Imagery of the Earth produced by satellite sensors exists for about six decades, and led early to the development of methods for estimating DSSI (Tarpley, 1979).

Today, the information from multi-channel satellite measurements offers the possibility to derive cloud physical properties and then compute cloud attenuation of the solar radiation with methods like the Fast All-sky Radiation Model For Solar Applications (FARMS) (Xie et al., 2016), Heliosat-4 (Qu et al., 2017), Zhang et al. (2018), or Hao et al. (2019). Such methods are especially advantageous for highly reflective regions, where clouds are difficult to discriminate from the ground. Nevertheless, they require information on more than one spectral channel, limiting their versatility in the choice of satellite sensor.

The use of radiative transfer models and look-up tables is also quite common in the field of satellite-based estimation of DSSI, but usually requires pre-existing informations on cloud properties or a cloud mask (e.g. ISCCP-F (Zhang, 2004), GEWEX-SRB (Pinker and Laszlo, 1992; Cox et al., 2017), CLARA (Mueller et al., 2009), Cloud_cci (Stengel et al., 2020; Stephens et al., 2001)).

Another group of methods, labeled as "cloud-index methods", are able to produce estimates of downwelling surface solar irradiance from the visible imagery of satellite radiometers without external knowledge on cloud physical and optical properties. This gives them potential to retrieve multi-decadal time series including from the imagery of oldest 2-channel sensors like the Meteosat Visible and Infrared Imager (MVIRI). Cloud-index methods emerged quite early, notably with the seminal work of Möser and Raschke (1983) and the first Heliosat method (Cano et al., 1986; Cano, 1982). The cloud index quantity derives from the radiances measured by spaceborne sensors, and relates them to the extinction of the DSSI caused by clouds. The greater the cloud index, the greater the extinction, and the smaller the DSSI. More precisely, the cloud index can be used as an 
empirical proxy for effective cloud transmissivity. The latter, also named "clear-sky index" within the scientific community of solar energy, is defined as the ratio of the all-sky surface irradiance to the clear-sky surface irradiance (Long and Turner, 2008; Beyer et al., 1996), i.e. the DSSI in cloud-free conditions.

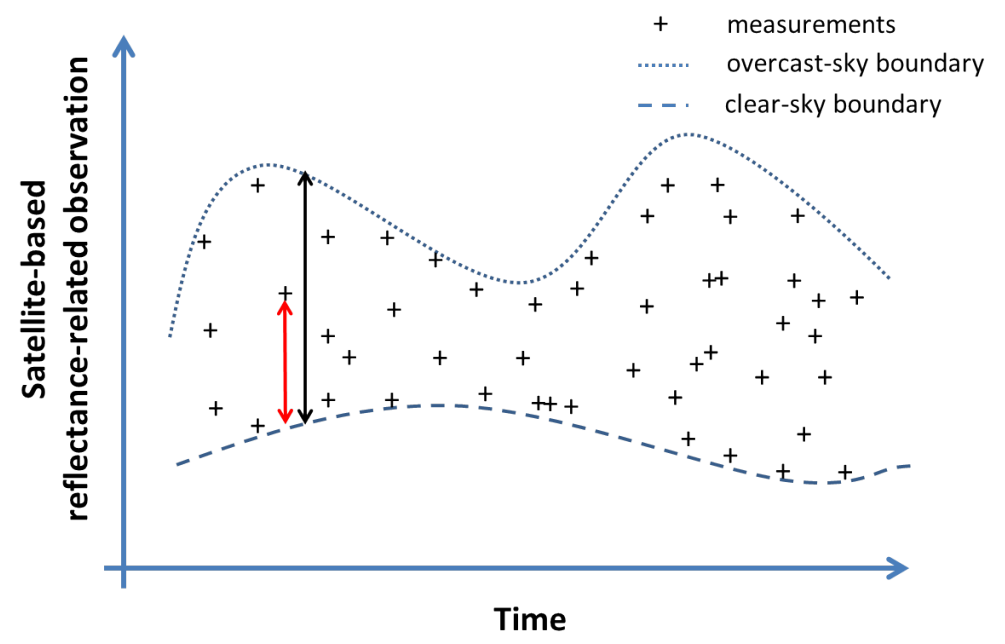

Figure 1. The calculation of a cloud index for a given location. The cloud index is the ratio between the distances "measurement to clear-sky" (red arrow) and "overcast-sky to clear-sky" (black arrow).

The cloud-index concept is based on the idea that the presence of a cloud brightens locally pixels of satellite shortwave imagery. In general, the value that quantifies reflectances of a given location observed from the top of the atmosphere (TOA), is comprised between a low and a high boundary values. The low boundary value $X_{\min }$ is taken as the clear-sky case and the high one $X_{\max }$ as the most cloudy case. The attenuation of downwelling surface solar irradiance by clouds is roughly given as a linear function of the difference between the measured value $X_{\text {sat }}$ and the clear-sky boundary, relatively to the cloudy case clear case difference, as illustrated in Figure 1. The cloud index $n$ is then given as:

$n=\frac{X_{\mathrm{sat}}-X_{\min }}{X_{\max }-X_{\min }}$

Differences between cloud-index methods mainly rely on :

- modifications of the relationship between the cloud index and the effective cloud transmissivity (Zarzalejo et al., 2009; Perez et al., 2002; Gupta et al., 2001; Rigollier and Wald, 1998);

- the choice of the variable used to calculate the cloud index, for example TOA albedo (Darnell et al., 1988), reflectance (Wang et al., 2014; Gupta et al., 2001; Möser and Raschke, 1984)), Lambert equivalent reflectivity (LER) (Herman et al., 2018; Dave, 1978) or raw satellite numerical counts (Pfeifroth et al., 2017; Perez et al., 2002);

- the way to retrieve the $X_{\max }$ and $X_{\min }$ for the chosen variable. 
If very different approaches are used to estimate the upper boundary, the lower boundary is "archive-based", in most literature we reviewed: it is a minimum based on a time series of past satellite imagery. Such an approach is hardly appliable to non geostationary satellites due to variable viewing geometries and a low revisit time. As an example, Wang et al. (2014) use a climatology of surface albedo to derive DSSI from the Ozone Monitoring Instrument (OMI), embedded on the sun-synchronous satellite Aura.

In this paper, we aim at finding an alternative to the need for archives of satellite imagery. It would then be easier to consider imagery from non-geostationary spaceborne platforms and produce a worldwide coverage. It would also let the results more reproducible, by making each instantaneous estimate independent of the preceding time series. Other drawbacks are frequent in archive-based methods such as systematic underestimations of the lower boundary $X_{\min }$ (e.g. unusual dark shadows on the ground taken as the clear-sky reference), contamination of $X_{\min }$ by clouds for cloudiest regions and of course, the difficulty to find a trade-off between a large time window that ensures the observation of clear sky instants, and a small one that captures the temporal variability of $X_{\min }$.

But the development of an alternative to such archive-based approaches also means dealing with new issues: previous methods based on archives can be less dependent on absolute calibration of the original imagery (Pfeifroth et al., 2017; Perez et al., 2002) and consider implicitely the anisotropy of $X_{\min }$. The pixel-to-pixel estimation of $X_{\min }$ is a surrogate for modeling the influence of viewing geometry on measured reflectances, while the slot-by-slot temporal characterization of $X_{\min }$ pictures the influence of varying solar-viewing geometry for the diurnal cycle of each pixel's reflectivity.

We aim at developing an alternative "stateless" method to extend the application field of the cloud-index approach to a wider variety of orbits and optical shortwave sensors. In order to limit the effects of molecular scattering, ozone absorption and polarization present in the ultraviolet, and of the absorption of radiation by clouds in the near infrared, the method considers satellite imagery in the spectral range $400-1000 \mathrm{~nm}(\lambda<1000 \mathrm{~nm})$. This range is also wide enough to permit the use of imagery from many meteorological satellite imagers launched since the beginnings of spaceborne Earth observation (e.g. different generations of the Advanced Very High Resolution Radiometer and of GOES, Meteosat and Himawari radiometers). Heliosat-V makes an extensive use of simulations from a radiative transfer model to estimate the upper boundary variables $X_{\min }$ and $X_{\max }$, which are here reflectances at the top of the atmosphere. This notably relies on the hypothesis that the absolute calibration of the satellite measurements is sufficiently well-known to ensure the quality of DSSI retrievals. It also means that the spectral sensitivity of the sensor and the anisotropy of reflectances caused by surface and atmospheric components have to be explicitely described to produce accurate estimates.

105 The impact of the anisotropy of surface reflectance has notably been shown for estimates of a cloud index derived from measurements of the ultraviolet/visible Global Ozone Monitoring Experiment 2 (GOME-2) and OMI by Lorente et al. (2018). The latter study also highlights the improvement of simulated shortwave clear-sky reflectances at the TOA, when using a model of bidirectional reflectance distribution function (BRDF) parameterized with data derived from the Moderate Resolution Imaging Spectroradiometer (MODIS) spaceborne instruments. 
The method foreseen to compute the cloud index of Heliosat-V and eventually the DSSI is described in Section 2, along with the protocol of validation. Validation results are presented in Section 3 for simulated reflectances at the top of the atmosphere and for downwelling surface solar irradiance estimates. Section 4 is dedicated to the discussion of results, and Section 5 to the conclusion and perspectives.

\section{Methods}

\subsection{The cloud index $n$}

As stated in the introduction, Heliosat-V is a method approximating the attenuation of DSSI radiation by clouds with a cloud index, $n$. Here, the cloud index components are reflectances considered at the top of the atmosphere (TOA), and corresponding to the satellite radiometer viewing geometry and spectral sensitivity. Reflectances are defined by the relation:

$120 \rho=\frac{\pi L}{E_{0} \cos \left(\theta_{\mathrm{s}}\right)}$

with $L$ the upwelling radiance at TOA for a given spectral channel, $E_{0}$ the downwelling spectral solar irradiance at the top of the atmosphere on a perpendicular plan weighted by the spectral response function (SRF) of the channel, and $\theta_{\mathrm{S}}$ the solar zenith angle for a given location (i.e. latitude and longitude) and a given time. $E_{0}$ varies mainly with the Sun-Earth distance, computed here with the Solar Geometry 2 algorithm (Blanc and Wald, 2012). The cloud index is then defined as:

$n=\frac{\rho_{\text {sat }}-\rho_{\text {clear }}}{\rho_{\text {ovc }}-\rho_{\text {clear }}}$

where $\rho_{\text {sat }}$ is the reflectance measured by the radiometer for the given spectral channel, while $\rho_{\text {clear }}$ and $\rho_{\text {ovc }}$ are estimates of the reflectance that would be measured by the same sensor for, respectively, a clear-sky scene, and an overcast scene, i.e. with an optically thick cloud covering the whole pixel considered. The notion of "optically thick cloud" will be described in detail in the subsection 2.3.

Because of its definition, the cloud index may also be calculated with radiances. We consider here reflectances in order to visualize the anisotropic nature of different scenes. It has also the advantage to be a normalized quantity, so we can compare results for different radiometric channels and different SZAs.

The relationship between $n$ and DSSI varies slightly from one method to another, in particular for highest and lowest values of $n$. The core of the relationship for intermediate values of $n$ follows usually:

where $G$ is the all-sky DSSI and $G_{\mathrm{c}}$ is the DSSI in clear-sky conditions and is provided by an external model. The external model used in this paper will be presented and discussed in section 2.4. The clear-sky index $K_{\mathrm{c}}$ is largely used to simplify the reading and is defined as:

$$
K_{\mathrm{c}}=\frac{G}{G_{\mathrm{c}}}
$$


$G=G_{\mathrm{c}} K_{\mathrm{c}}$

Several modifications of the relation $K_{\mathrm{c}}(n)$ have been proposed, e.g. by Rigollier and Wald (1998) (reported in Rigollier et al. (2004)); Gupta et al. (2001); Perez et al. (2002); Zarzalejo et al. (2009). In this paper, we keep the original and simple relation $K_{\mathrm{c}}=1-n$ introduced by Darnell et al. (1988) as its optimization is out of the scope of this work. In the following subsections, we describe the method used to compute $\rho_{\text {clear }}, \rho_{\text {ovc }}$ and $G_{\mathrm{c}}$.

\subsection{The clear-sky reflectances $\rho_{\text {clear }}$}

We use a radiative transfer model to estimate what a spaceborne optical imaging system would measure in clear-sky conditions, for a given radiometric channel. Using simulations in cloud indices has previously been done notably to retrieve effective cloud fractions from the OMI instrument (Lorente et al., 2018; Veefkind et al., 2016; Stammes et al., 2008). We apply the same approach to satellite radiometers.

Radiative transfer simulations are able to estimate reflected radiation at the top of the atmosphere (TOA) considering the non-lambertian nature of the atmosphere and of Earth's surfaces. For the implementation of the method applied here, we use the model uvspec within the software package libRadtran (version 2.0.2) (Emde et al., 2016) and the one-dimension solver DISORT (Buras et al., 2011). We chose to use 32 streams for DISORT as a good compromise between time computation and a good angular representativeness of simulated radiances. For the spectral description, radiative transfer simulations are made following the so-called REPTRAN spectral approximation (Gasteiger et al., 2014). This parameterization enables the production of fast computations of radiative transfer adapted to the spectral sensitivity of satellite radiometric channels.

The spectral description of downwelling solar irradiance at the top of the atmosphere is provided by data from Kurucz (1992) for simulating $\rho_{\text {clear }}$. The composition of the atmosphere is prescribed by time series of total atmospheric columns of ozone and water vapour from the Monitoring Atmospheric Composition and Climate (MACC) reanalysis (Inness et al., 2013) distributed by the ECMWF. The atmospheric abundance profiles of $\mathrm{O}_{2}, \mathrm{CO}_{2}$ and $\mathrm{NO}_{2}$ are kept to the fixed values of the Air Force Geophysics Laboratory (AFGL) midlatitude summer profile (Anderson et al., 1986), along with the temperature, pressure and air density profiles.

Partial aerosol optical depths (AOD) are provided at the wavelength $550 \mathrm{~nm}$, for 5 types of aerosols (black carbon, dust, sea salt, organic matter, sulfate) by the Monitoring Atmospheric Composition and Climate (MACC) reanalysis. A more recently developed product Copernicus Atmospheric Monitoring Service (CAMS) reanalysis exists, with two supplementary classes "ammonium" and "nitrate" added to the aerosol categories of the service. It is worth mentioning that we do not use it, even such change would not affect the method itself.

An algorithm developed by Lefèvre et al. (2013) translates MACC partial aerosol optical depths information into aerosol mixtures designed for the Optical Properties of Aerosols and Clouds (OPAC) software package (Hess et al., 1998). These mixtures are associated to aerosol properties: scattering and absorbing coefficients, single scattering albedo, asymmetry parameter and the Angström coefficient. The total AOD at $550 \mathrm{~nm}$ is then calculated as the sum of partial AOD at $550 \mathrm{~nm}$ provided by 
CAMS. As libRadtran needs a total AOD input for the simulated wavelength, the OPAC Angström coefficient of the given mixture is used to estimate the AOD at the required wavelength.

The reflective properties of land surfaces are described with the RossThick-LiSparse (Ross-Li) model of bidirectional reflectance distribution function (Roujean et al., 1992; Lucht et al., 2000). It is then possible to consider the variations of the surface reflectance depending on viewing and solar zenith angles and on the azimuthal difference of both geometries $\Delta \phi$. The Ross-Li model decomposes the BRDF of a surface into a sum of three components: an isotropic contribution, independent of viewing and solar geometries; a volumic contribution, following a mathematical model of an idealized canopy ; and a geometric contribution, considering the shadows induced by the roughness of the surface.

Algorithms have been developed to estimate the parameters $f_{\text {iso }}, f_{\mathrm{vol}}$ and $f_{\text {geo }}$ that weight respectively each of the contributors to the surface reflectance for all lands. This has notably been made with the imagery produced by the Moderate Resolution Imaging Spectroradiometer (MODIS) embedded on Terra and Aqua satellites (Wanner et al., 1997; Lyapustin et al., 2018).

We test here simulations with data from the Algorithm for Modeling MODIS Bidirectional Reflectance Anisotropies of the Land Surface (AMBRALS) (Wanner et al., 1997) with its derived product MCD43C1 v6 (Schaaf et al., 2002).

This product provides $f_{\text {iso }}, f_{\text {vol }}$ and $f_{\text {geo }}$ parameters with a $0.05^{\circ}$ resolution (about $6 \mathrm{~km}$ at the equator), a daily sampling rate, 16-day average and for seven spectral channels, including 4 channels in the 400-1000 nm spectral interval considered for the Heliosat-V method (Fig. 3). Owing to libRadtran documentation (Mayer et al., 2017), the values of each parameter are assigned to the central wavelength of its channel and a linear spectral interpolation is applied for the radiative transfer calculations. For wavelengths shorter than the $0.47 \mu \mathrm{m}$ MODIS channel, values are considered spectrally constant. For wavelengths longer than $0.85 \mu \mathrm{m}$, the interpolation is made between parameters at MODIS channels $0.86 \mu \mathrm{m}$ and $1.24 \mu \mathrm{m}$.

\subsection{The overcast-sky reflectances $\rho_{\text {ovc }}$}

Cloud-index methods in the literature use various ways to estimate the TOA reflectances in overcast conditions $\rho_{\text {ovc }}$ (Perez et al., 2002; Lefèvre et al., 2007; Pfeifroth et al., 2017). One way to approximate it without the use of archives of satellite imagery has been proposed within the Heliosat-2 framework (Lefèvre et al., 2007). An empirical relation based on the work of Taylor and Stowe (1984) was developed, considering a dependency of $\rho_{\text {ovc }}$ with the single solar zenith angle $\theta_{\mathrm{s}}$.

$\rho_{\text {ovc }, \mathrm{HS} 2}=0.85-0.13\left[1-\exp \left(-4 \cos \left(\theta_{\mathrm{s}}\right)^{5}\right)\right]$

However, spectral radiative transfer simulations of $\rho_{\text {ovc }}$ show that there is also a significant dependency between the TOA cloudy reflectances and other variables. In Figure 2, we represent 2-dimension histograms of TOA reflectances calculated from such simulations, with a solar zenith angle set to $30^{\circ}$ as an example. For most wavelengths, a significant spread of the distribution is observed (Fig. 2, two upper rows), corresponding only to different viewing geometries defined by a linear meshgrid in cosine of viewing zentih angle $\left(\theta_{\mathrm{v}}\right)$ and difference $\Delta \phi$ of solar and viewing azimuth angles (Table 1).

In this paper, we assume a cloud optical thickness (COT) of 150 to define optically thick clouds and overcast conditions. This assumption relies on COT statistics from retrievals by the International Satellite Cloud Climatology Project (ISCCP) and surface measurements of irradiance shown by Trishchenko et al. (2001). The simulations for a low thick cloud (cloud top 


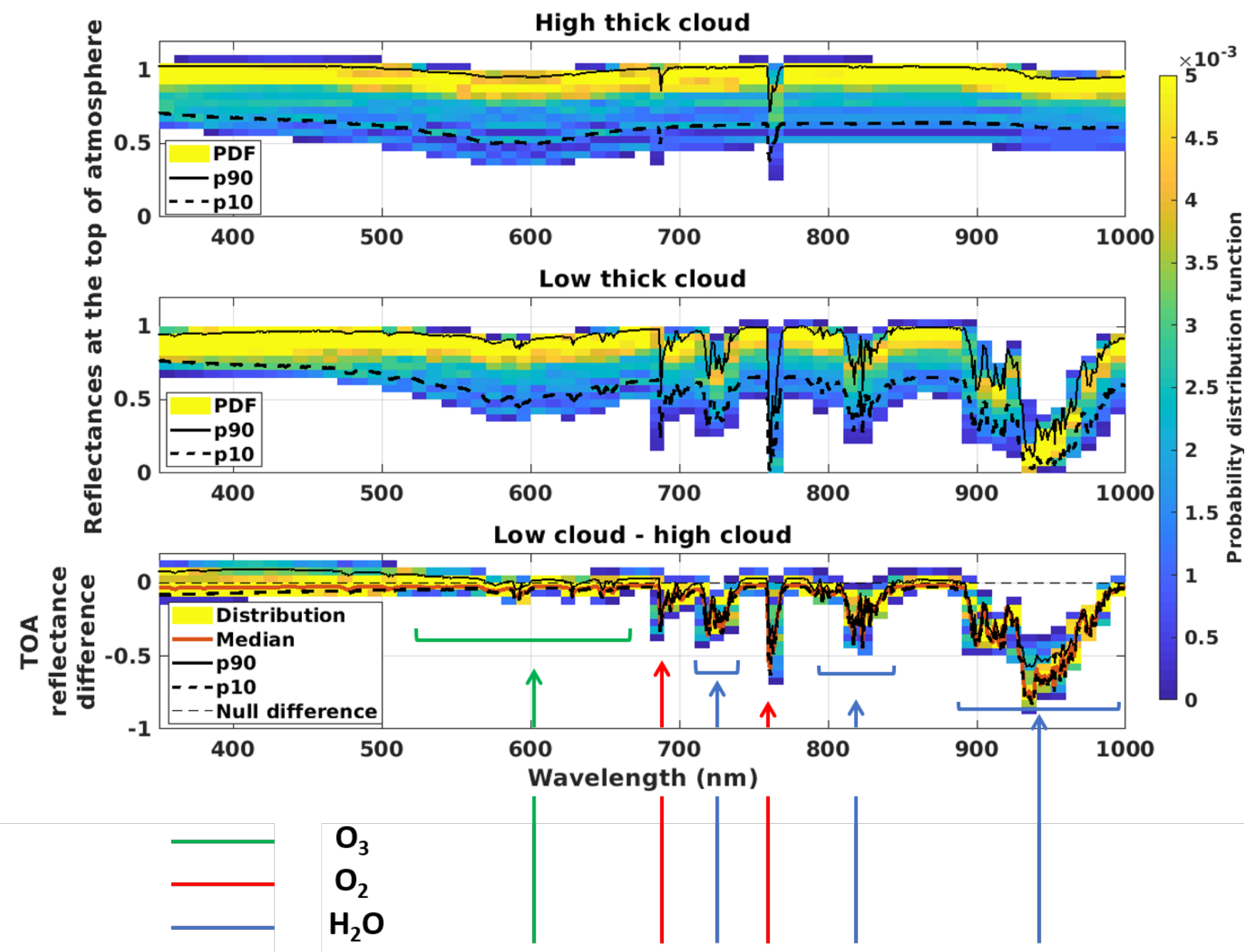

Figure 2. Two upper rows : distributions of simulated TOA reflectance spectra in overcast conditions $\rho_{\text {ovc }}$ for the different viewing geometries in the look-up table and for a solar zenith angle of $30^{\circ}$, with a thick liquid cloud (COT =150). First row: CTH $=15 \mathrm{~km}$; cloud base height $(\mathrm{CBH})=2 \mathrm{~km}$. Second row: $\mathrm{CTH}=0.5 \mathrm{~km} ; \mathrm{CBH}=0.2 \mathrm{~km}$. Third row: error on $\rho_{\text {ovc }}$ caused by a misattribution of cloud height to the "low thick cloud" category. Green, red and blue arrows indicate spectral regions with main absorption features from $\mathrm{O}_{3}, \mathrm{O}_{2}$ and $\mathrm{H}_{2} \mathrm{O}$, respectively.

height $(\mathrm{CTH})$ at $500 \mathrm{~m})$ and a high thick cloud $(\mathrm{CTH}$ at $15 \mathrm{~km}$ ) show in general a good agreement, except in absorbing bands of $\mathrm{O}_{2}$ (mainly at $690 \mathrm{~nm}\left(\mathrm{O}_{2}\right.$-B band) and $762 \mathrm{~nm}\left(\mathrm{O}_{2}\right.$-A band)) and $\mathrm{H}_{2} \mathrm{O}$ (mainly at $725 \mathrm{~nm}, 820 \mathrm{~nm}$ and $950 \mathrm{~nm}$ ) and for short wavelengths where scattering becomes increasingly significant (e.g. Jin et al. (2011)). For these wavelengths, the TOA 
reflectances with low clouds can be much lower than for high clouds, for a given cloud optical thickness. But outside these specific spectral regions, the height of clouds will not affect significantly the results of the method.

An alternative way is therefore to produce look-up tables (LUT) from radiative transfer simulations, an approach notably applied in the framework of the Heliomont cloud-index method to the Spinning Enhanced Visible and Infra-Red Imager (SEVIRI) High Resolution Visible channel (HRV) (Stöckli, 2014). It is then possible to take into account the viewing geometry and also the spectral variability of $\rho_{\text {ovc }}$. Assumptions have to be made on the properties of the optically thick clouds as the Heliosat-V method is designed to work by using only one spectral channel in the range 400-1000 nm: cloud top height, phase of cloud, cloud optical thickness, cloud droplet radius or ice crystal shape and size.

Here we construct a liquid cloud LUT of $\rho_{\text {ovc }}$, setting different cloud and atmosphere properties, geometry and spectral grids, as described in Table 1. The optical properties of the clouds come from the precalculated Mie tables provided by the libRadtran software package.

As no information is provided on the actual cloud vertical structure, $\rho_{\text {ovc }}$ are calculated as :

$\rho_{\text {ovc }}=\frac{1}{2}\left(\rho_{\text {ovc }, \text { high }}+\rho_{\text {ovc }, \text { low }}\right)$

where $\rho_{\text {ovc,high }}$ and $\rho_{\text {ovc,low }}$ are respectively derived from the high and low liquid cloud LUTs, interpolated on the viewing and solar geometries of the satellite time series and adapted to the spectral response function of radiometric channels.

An ice cloud LUT is also produced, to study the sensitivity of surface irradiance estimates to the assumed cloud phase. The ice cloud characteristics follow the parameterization by Yang et al. (2013). We use the "aggregate of 8 columns" ice crystal habit and the "severe" degree of roughness, which are notably used for the description of ice clouds in the look-up table of the MODIS collection 6 cloud product (Amarasinghe et al., 2017).

\subsection{The clear-sky model of surface irradiance $G_{c}$}

The clear-sky surface irradiance is given by the the version 3 of the McClear model (Gschwind et al., 2019). The McClear model is a fast and accurate model that provides clear-sky estimation of DSSI with an absolute bias below $21 \mathrm{~W} \mathrm{~m}^{-2}$ and a standard deviation error below $25 \mathrm{~W} \mathrm{~m}^{-2}$ for 6 BSRN stations used in this paper, namely: Brasilia, Carpentras, Palaiseau, Payerne, Sede Boker and Tamanrasset. The McClear model was fed with the partial optical depths at $550 \mathrm{~nm}$ for black carbon, dust, sea salt, organic matter and sulfate from MACC reanalysis. It is also fed by water vapor atmospheric total columns ant the ozone total columns provided by ECMWF. Data was dowloaded from the McClear web service (http://www.soda-pro.com/ web-services/radiation/cams-mcclear).

\subsection{Set-up of validation}

To study the validity of the method, we compare DSSI estimates from MSG satellite measurements with pyranometric DSSI data retrieved from measurement stations part of the reference Baseline Surface Radiation Network (BSRN) (Ohmura et al., 1998; Driemel et al., 2018). Considered stations are listed in Table 2 and displayed in the MSG field of view in Figure 4. Only 
https://doi.org/10.5194/amt-2020-480

Atmospheric

Preprint. Discussion started: 12 February 2021

(c) Author(s) 2021. CC BY 4.0 License.

Table 1. Characteristics of the look-up table of cloudy TOA reflectances

\begin{tabular}{|c|c|}
\hline Characteristics & Values \\
\hline Cloud phase & liquid (ice only for sensitivity tests) \\
\hline Cloud optical thickness (COT) & 150 \\
\hline Cloud droplet radius & vertical profile between 8 and $12 \mu \mathrm{m}$ \\
\hline Cloud top height $(\mathrm{CTH})$ & $500 \mathrm{~m} ; 15 \mathrm{~km}$ \\
\hline Solar zenith angle $\left(\theta_{\mathrm{s}}\right)$ & $0^{\circ}: 5^{\circ}: 85^{\circ}$ \\
\hline cosine of viewing zenith angle $\left(\cos \theta_{\mathrm{v}}\right)$ & $0.1: 0.1: 1$ \\
\hline difference of solar and viewing azimuth angles $(\Delta \phi)$ & $0^{\circ}, 5^{\circ}, 10^{\circ}: 20^{\circ}: 170^{\circ}, 175^{\circ}, 180^{\circ}$ \\
\hline Spectral resolution & $1 \mathrm{~nm}$ \\
\hline TOA spectrum & Gueymard (2018) \\
\hline Ozone total column & 300 Dobson Units (DU) \\
\hline Water vapour total column & $20 \mathrm{~kg} \mathrm{~m}^{-2}$ \\
\hline Aerosols & default aerosol described in Shettle (1990) \\
\hline Temperature and pressure profiles & AFGL midlatitude summer \\
\hline
\end{tabular}

Table 2. List of BSRN stations used for validation

\begin{tabular}{c|c|c|c|c}
\hline Station & Code & Latitude & Longitude & Elevation \\
\hline Brasilia & BRB & $15.6010^{\circ} \mathrm{S}$ & $47.7130^{\circ} \mathrm{W}$ & $1023 \mathrm{~m}$ \\
Cabauw & CAB & $51.9711^{\circ} \mathrm{N}$ & $4.9267^{\circ} \mathrm{E}$ & $0 \mathrm{~m}$ \\
Camborne & CAM & $50.2167^{\circ} \mathrm{N}$ & $5.3167^{\circ} \mathrm{W}$ & $88 \mathrm{~m}$ \\
Carpentras & CAR & $44.083^{\circ} \mathrm{N}$ & $5.590^{\circ} \mathrm{E}$ & $100 \mathrm{~m}$ \\
CENER & $\mathrm{CNR}$ & $42.8160^{\circ} \mathrm{N}$ & $1.6010^{\circ} \mathrm{W}$ & $471 \mathrm{~m}$ \\
Lindenberg & $\mathrm{LIN}$ & $52.2100^{\circ} \mathrm{N}$ & $14.1220^{\circ} \mathrm{E}$ & $125 \mathrm{~m}$ \\
Palaiseau & $\mathrm{PAL}$ & $48.7130^{\circ} \mathrm{N}$ & $2.2080^{\circ} \mathrm{E}$ & $156 \mathrm{~m}$ \\
Payerne & $\mathrm{PAY}$ & $46.8150^{\circ} \mathrm{N}$ & $6.9440^{\circ} \mathrm{E}$ & $491 \mathrm{~m}$ \\
Sede Boker & $\mathrm{SBO}$ & $30.8597^{\circ} \mathrm{N}$ & $34.7794^{\circ} \mathrm{E}$ & $500 \mathrm{~m}$ \\
Sao Martinho da Serra & $\mathrm{SMS}$ & $29.4428^{\circ} \mathrm{S}$ & $53.8231^{\circ} \mathrm{W}$ & $489 \mathrm{~m}$ \\
Tamanrasset & $\mathrm{TAM}$ & $22.7903^{\circ} \mathrm{N}$ & $5.5292^{\circ} \mathrm{E}$ & $1385 \mathrm{~m}$ \\
\hline
\end{tabular}

240 the highest quality BSRN measurements of surface irradiance are used, having passed a quality check (Lefèvre et al., 2013). Figure 5 shows the time series when data are considered valid, for each station. 


\section{DSCOVR/EPIC}
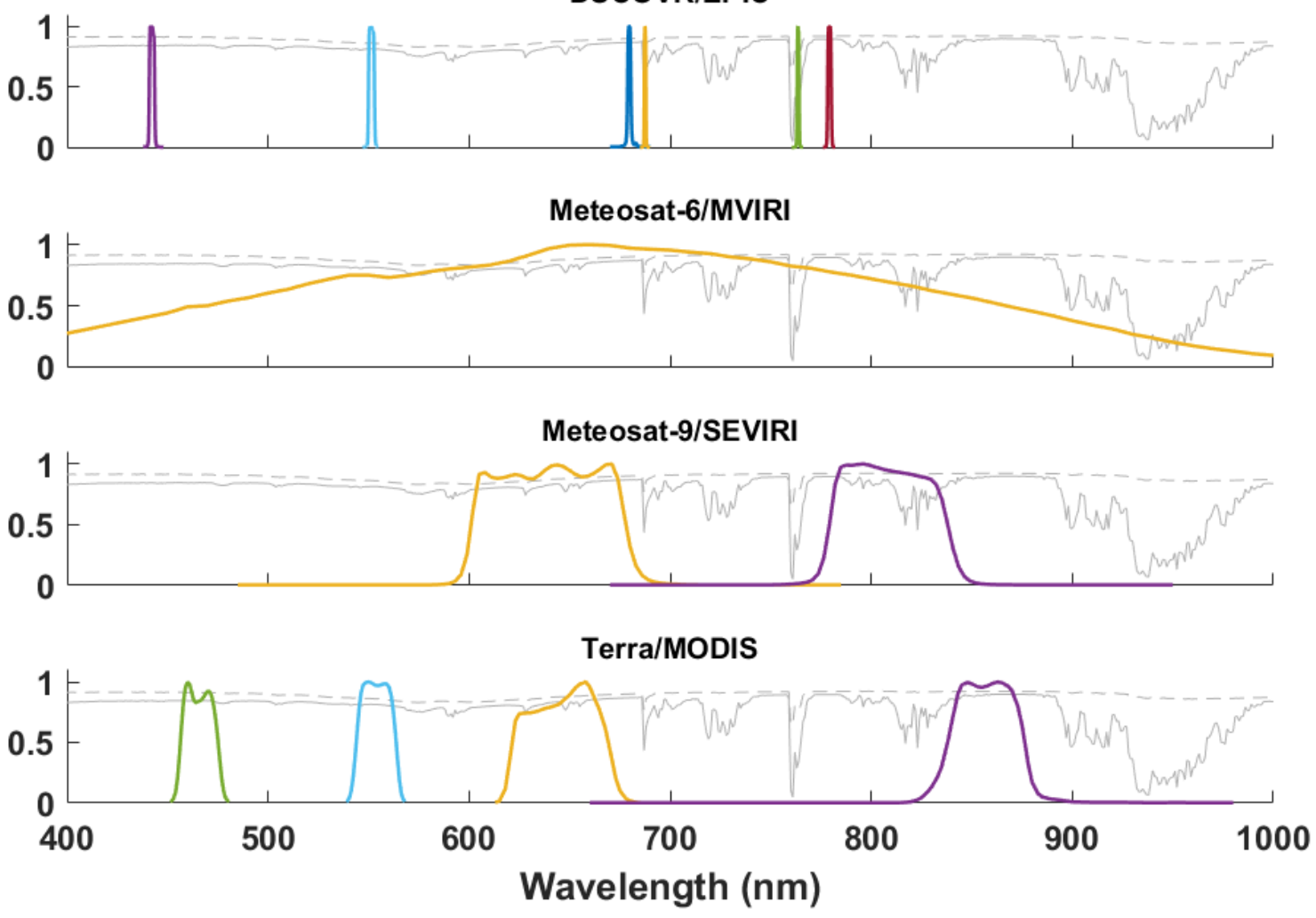

Figure 3. Colored lines: spectral response functions of different sensors in the spectral range considered by Heliosat-V. Gray lines : TOA reflectance spectra of typical scenes with a high (dashed line) and low altitude (solid line) thick cloud 
https://doi.org/10.5194/amt-2020-480

Preprint. Discussion started: 12 February 2021

(c) Author(s) 2021. CC BY 4.0 License.

(c) (i)
Atmospheric Measurement Techniques

Discussions

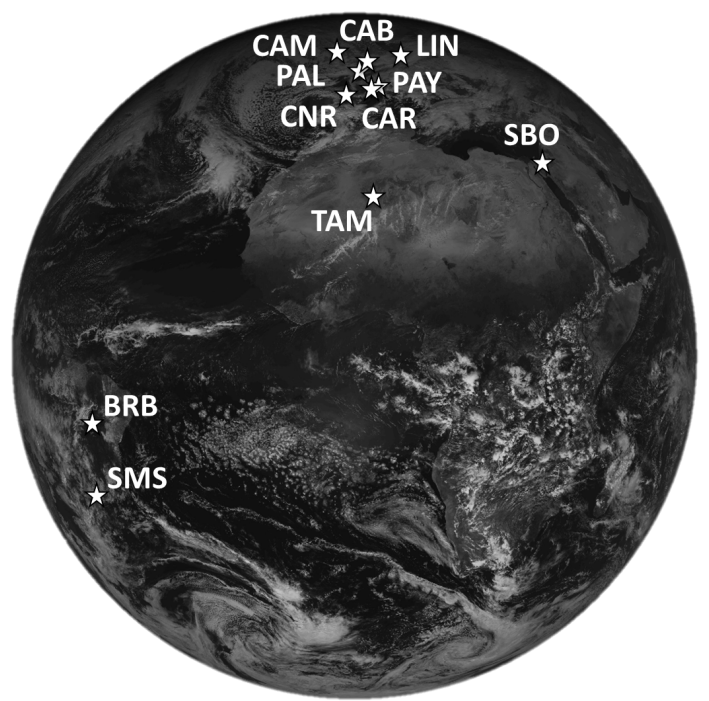

Figure 4. BSRN ground stations used for validation in this study, in the field of view of Meteosat Second Generation $(0.6 \mu \mathrm{m}$ channel).

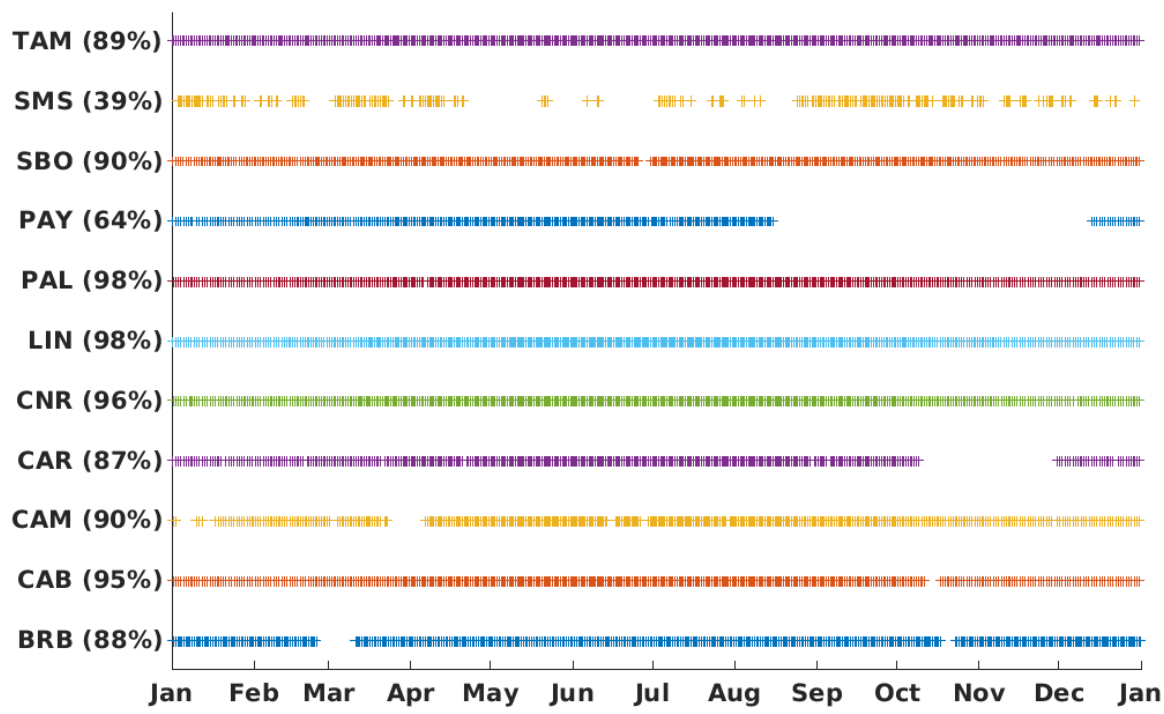

Figure 5. Time series used for the 15-min mean statistics between satellite estimates and quality-checked BSRN measurements during the year 2011. In parentheses : percentage of data conserved. 
The method has been tested on images from the SEVIRI sensor, aboard the Meteosat-9 meteorological geostationary satellite belonging to the family of Meteosat Second Generation (MSG). We consider measurements in the solar channels $0.6 \mu \mathrm{m}$ and $0.8 \mu \mathrm{m}$ channels, for the year 2011 and for 11 locations in the field of view of the satellite, and corresponding to locations of pyranometric in situ sensors from the BSRN network.

We use the calibration coefficients provided by EUMETSAT that operates MSG. This is worth noting as some calibration methods recommend to use significantly different gain factors to compute radiances from raw numerical counts (e.g. Doelling et al. (2018)). The use of optimal calibration is out of the scope of our work. Still, we compared gains coefficients proposed by EUMETSAT $g_{\mathrm{EUM}}$ with those provided by Doelling et al. (2018) $g_{\mathrm{D} 2018}$ for the measurements produced by the Meteosat-9 0.6 and $0.8 \mu \mathrm{m}$ channels in 2011 . They show a mean disagreement, calculated as $\left(g_{\mathrm{EUM}}-g_{\mathrm{D} 2018}\right) / g_{\mathrm{D} 2018}$, of about $-9 \%$ for $0.6 \mu \mathrm{m}$ and $-8 \%$ for $0.8 \mu \mathrm{m}$ during this period (also illustrated on Fig. A1). Such errors will affect with the same magnitude the agreement between numerical simulations and measurements of clear-sky TOA reflectances, underlining the importance of absolute calibration for the Heliosat-V method.

To compare the results of our method to operational satellite-based products of surface irradiance, we use data from HelioClim3 version 5 (HC3v5) and CAMS Radiation (CAMS-RAD) DSSI databases. Both are derived from the imagery of the SEVIRI sensor and are produced by a Heliosat method: a modified version of Heliosat-2 for HC3v5 (Qu et al., 2014) and Heliosat4 for CAMS-RAD. Boths products and their descriptions are provided by the SoDa service (http://www.soda-pro.com/).

All validation results thereafter are produced for solar zenith angles lower than $80^{\circ}$.

\section{Results}

\subsection{The cloud index components}

\subsubsection{Simulated TOA clear-sky reflectances $\rho_{\text {clear }}$}

As an intermediate assessment, simulated clear-sky reflectances at the top of the atmosphere (TOA) $\rho_{\text {clear }}$ are compared to satellite measurements. Cloudy instants are manually filtered out of the satellite time series. Results comprising all the manuallyfiltered clear-sky instants in 2011 for all the eleven sites, are shown in Figure 6 as 2D reflectance histograms.

For the $0.6 \mu \mathrm{m}$ channel, the root-mean-square difference (RMSD) between simulated reflectances $\rho_{\text {clear }}$ and reflectances $\rho_{\text {sat }}$ measured in clear-sky conditions is about $0.03(15 \%)$, mainly due to a bias of about $0.02(10 \%)$. The relative value of the standard deviation of the difference (STD) is approximately $11 \%$ for both $0.6 \mu \mathrm{m}$ and $0.8 \mu \mathrm{m}$ channels. However reflectances in the near infrared $0.8 \mu \mathrm{m}$ channel are significantly higher, so is the absolute value of STD. Both higher STD and bias for the $0.8 \mu \mathrm{m}$ will cause a lower precision in the calculation of the cloud index than for $0.6 \mu \mathrm{m}$. Correlation coefficients are significantly high, both larger than 0.9 but the correlation is much better for $0.6 \mu \mathrm{m}$ with 0.974 : the variability of $\rho_{\text {clear }}$ is significantly better represented (almost $95 \%$ of the total variance) than for $0.8 \mu \mathrm{m}$ ( $82 \%$ of the total variance).

Figure 7 shows that estimates are able to reproduce partly the diurnal variability observed in clear sky conditions. When studying station by station, highest mean biases reach +0.035 for $0.6 \mu \mathrm{m}$ (Payerne) and -0.07 for $0.8 \mu \mathrm{m}$ (Camborne) (see also 
Fig. B1). It is worth noting that we use MCD43C1v6 BRDF data regardless of their quality flags. We observe although that
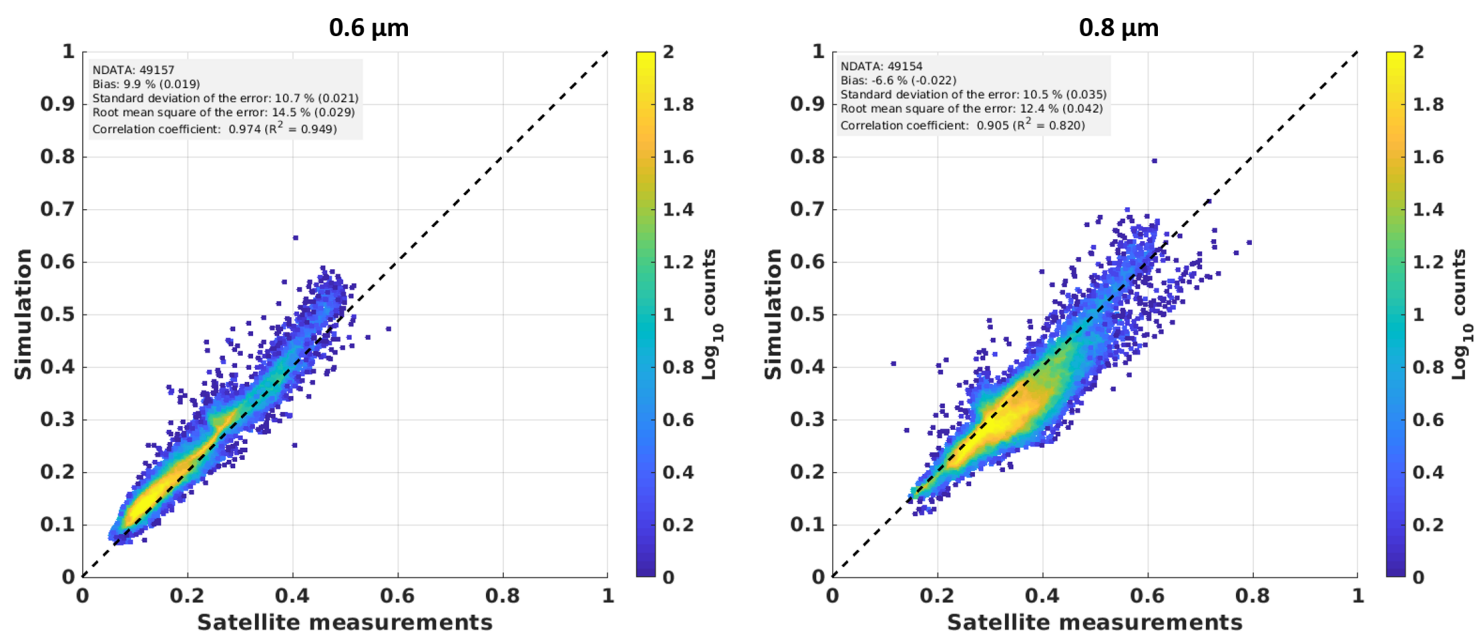

Figure 6. Simulation of clear-sky reflectances at the TOA $\left(\rho_{\text {clear }}\right)$ for MSG $0.6 \mu \mathrm{m}$ (left panel) and $0.8 \mu \mathrm{m}$ (right panel) spectral channels compared with actual satellite measurements. The comparison is done for all 11 locations, for the year 2011.

\subsubsection{Simulated reflectances at the top of the atmosphere in overcast conditions $\rho_{\text {ovc }}$}

The validity of $\rho_{\text {ovc }}$ is more difficult to test than that of $\rho_{\text {clear }}$ by comparing with satellite measurements as the occurence of optically thick clouds can be rare depending on the location, the season and the hour of the day. We therefore use 9 years of Meteosat measurements, between 2011 and 2019 to extract the $1 \%$ most reflective scenes for each station, month and hour of the day (Fig. 7). The first row of Figure 6 shows a good agreement between most reflective satellite scenes of the São Martinho da Serra pixel and $\rho_{\text {ovc }}$. On the other hand, some stations show regularly values of measured reflectances beyond the $\rho_{\text {ovc }}$ simulated boundary, as in the exemple of Camborne (Fig. 7, second row). Figure 7 illustrates also how $\rho_{\text {ovc }}$ depends on the liquid or ice phase of the cloud, due to their different scattering phase functions.

\subsection{Comparison of satellite-based estimates with ground-based measurements}

Validation results are shown in Table 3, for 15-min averaged DSSI estimates. Satellite-based estimates are obtained with MSG $0.6 \mu \mathrm{m}$ imagery. Results for MSG $0.8 \mu \mathrm{m}$ imagery show generally lower quality in terms of correlation and STD (Fig. B2). 

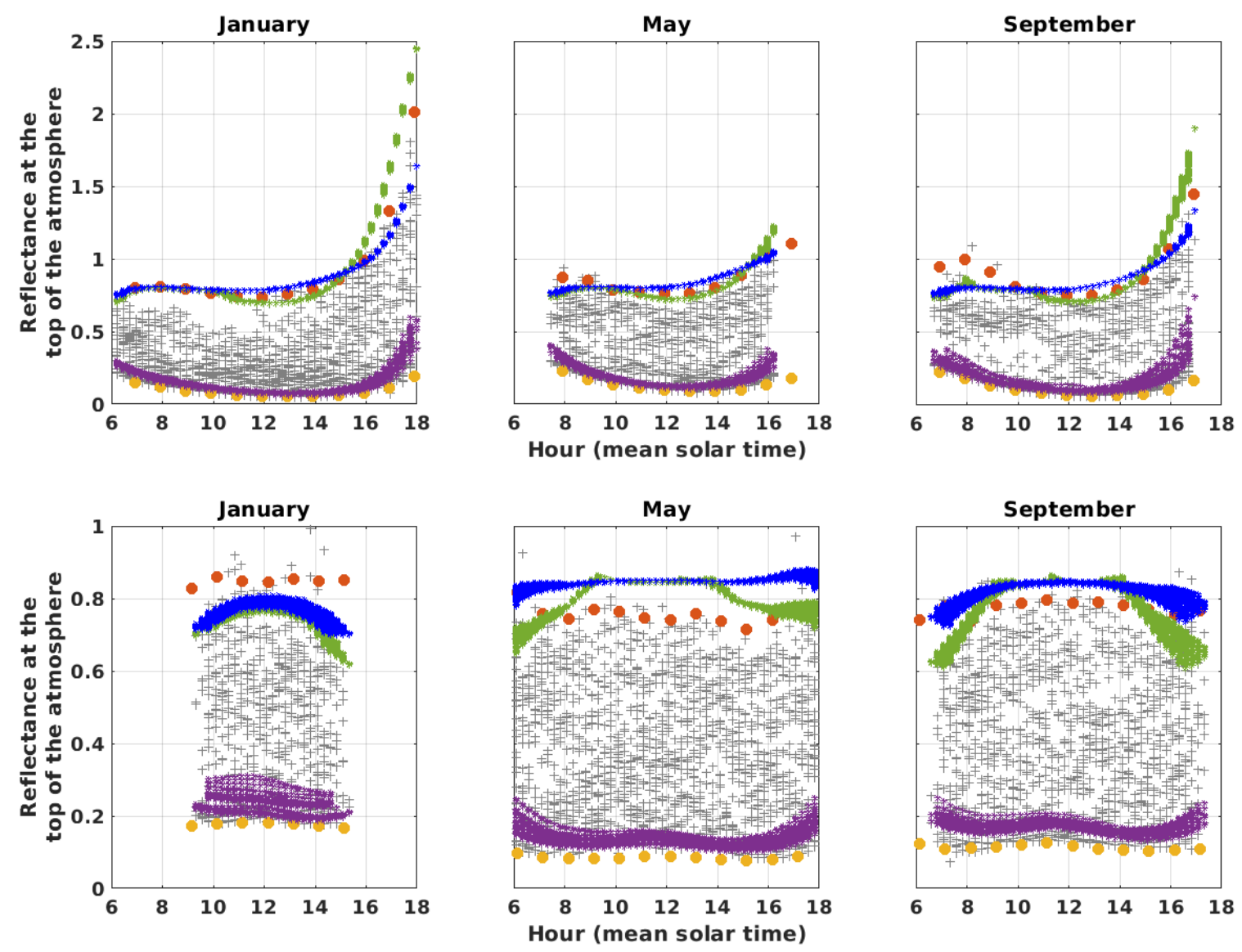

Figure 7. Simulated and measured reflectances at the top of the atmosphere above São Martinho da Serra (Brazil, upper row) and Camborne (United Kingdom, lower row) locations, for MSG 0.6 $\mu \mathrm{m}$ channel and for January, May and September calendar months. Grey plus signs: MSG measurements (2011, Meteosat-9). Green asterisks: reflectances in overcast conditions $\rho_{\text {ovc }}$, derived from the liquid-cloud look-up table. Blue asterisks: same from the ice-cloud look-up table. Purple asterisks: reflectances in clear-sky conditions $\rho_{\text {clear }}$, derived from radiative transfer simulations. Yellow and orange dots are respectively hourly percentiles 1 and 99 of MSG satellite measurements from year 2011 to 2019.

We tested the sensitivity of the DSSI estimates to the cloud phase by using in one case the reference look-up table, featuring a liquid cloud, and for the test case, an ice cloud as described in Section 2.3. Results show only minor differences, pointing out a limited influence of the cloud phase on DSSI estimates (Fig. B3).

\subsection{Comparison of satellite-based estimates with operational products HelioClim3 and CAMS Radiation}

The results of the method are also compared to satellite-based DSSI products HelioClim3 version 5 (HC3v5) and CAMS Radiation Service (CAMS-RAD) on Table 4. Results for the new HSV method show statistics similar to HC3v5 and CAMS- 
https://doi.org/10.5194/amt-2020-480

Preprint. Discussion started: 12 February 2021

(c) Author(s) 2021. CC BY 4.0 License.
Atmospheric

Measurement

Techniques

Discussions

Table 3. Validation results for 15-min means of all-sky DSSI, for the year 2011. Results based on the imagery of Meteosat-9/SEVIRI 0.6 $\mu \mathrm{m}$ channel.

\begin{tabular}{c|c|c|c|c|c}
\hline Station & Number of samples & $\begin{array}{c}\text { Mean BSRN } \\
\mathrm{W} \mathrm{m}^{-2}\end{array}$ & $\begin{array}{c}\text { Bias } \\
\mathrm{W} \mathrm{m}^{-2}(\%)\end{array}$ & $\begin{array}{c}\text { RMSD } \\
\mathrm{W} \mathrm{m}^{-2}(\%)\end{array}$ & $\begin{array}{c}\text { Correlation coefficient } \\
(\mathrm{R})\end{array}$ \\
\hline Brasilia & 13570 & 504 & $25(5)$ & $137(27)$ & 0.883 \\
Cabauw & 13222 & 301 & $4(1)$ & $72(24)$ & 0.949 \\
Camborne & 12731 & 310 & $-3(-1)$ & $103(33)$ & 0.901 \\
Carpentras & 12642 & 452 & $41(9)$ & $80(18)$ & 0.969 \\
CENER & 14164 & 412 & $21(5)$ & $89(22)$ & 0.946 \\
Lindenberg & 13637 & 317 & $9(3)$ & $81(26)$ & 0.938 \\
Palaiseau & 13993 & 335 & $12(4)$ & $79(24)$ & 0.948 \\
Payerne & 9191 & 387 & $29(8)$ & $88(23)$ & 0.955 \\
Sede Boker & 13574 & 589 & $46(8)$ & $90(15)$ & 0.960 \\
Sao Martinho da Serra & 5864 & 501 & $8(2)$ & $102(20)$ & 0.936 \\
Tamanrasset & 13609 & 579 & $26(5)$ & $88(15)$ & 0.958 \\
\hline Total & 136197 & 436 & $20(5)$ & $93(22)$ & 0.948
\end{tabular}

Table 4. Comparison between validation results of HSV with those of HC3v5 and CAMS-RAD, each one versus BSRN measurements. Statistics on 15-minute means of DSSI for the stack of 11 stations and the year 2011. N $=135107 ; \mathrm{BSRN}^{\mathrm{mean}}=424 \mathrm{~W} \mathrm{~m}^{-2}$

\begin{tabular}{c|c|c|c|c}
\hline Method/data product & $\begin{array}{c}\text { Bias } \\
\mathrm{W} \mathrm{m}^{-2}(\%)\end{array}$ & $\begin{array}{c}\text { STD } \\
\mathrm{W} \mathrm{m}^{-2}(\%)\end{array}$ & $\begin{array}{c}\text { RMSD } \\
\mathrm{W} \mathrm{m}^{-2}(\%)\end{array}$ & $\begin{array}{c}\text { Correlation coefficient } \\
(\mathrm{R})\end{array}$ \\
\hline HSV 0.6 $\mu \mathrm{m}$ & $20(5)$ & $91(21)$ & $93(22)$ & 0.948 \\
HSV 0.8 $\mu \mathrm{m}$ & $-6(-2)$ & $101(24)$ & $101(24)$ & 0.934 \\
HC3v5 & $2(0)$ & $88(21)$ & $88(21)$ & 0.950 \\
CAMS-RAD & $0(0)$ & $98(23)$ & $98(23)$ & 0.937 \\
\hline
\end{tabular}

RAD, for both estimates based on $0.6 \mu \mathrm{m}$ and $0.8 \mu \mathrm{m}$ channels, in terms of correlation and of STD. One may note very low values of bias for operational products. This is expected because CAMS-RAD and HC3v5 estimates are calibrated with DSSI measurements from a similar set of BSRN stations.

\section{Discussion}

Cloud-index methods are sensitive to estimates of clear-sky reflectances at the top of the atmosphere (TOA) $\rho_{\text {clear }}$, to the accuracy of overcast reflectances $\rho_{\text {ovc }}$ and to the contrast between clear-sky and overcast scenes. 
Better results from the channel $0.6 \mu \mathrm{m}$ could be attributed to a smaller influence of the cloud top height, compared to the $0.8 \mu \mathrm{m}$ channel which is affected by water vapour absorption (Fig. 3). Also, the choice of a spectral linear interpolation between MODIS channels to simulate surface reflectances in SEVIRI channels is supposed to contribute significantly to biases observed in $\rho_{\text {clear }}$ simulations, in particular for the $0.8 \mu \mathrm{m}$ channel with vegetated surfaces due to the red edge spectral pattern. Such biases could affect significantly DSSI estimates.

The surface reflectivity is lower for shorter wavelengths in general. Selecting a channel for which the surface reflectivity is low will favor a high contrast between clear-sky and overcast scenes, and improve the precision in the computation of the cloud index.

Our ability to reproduce reflectances at the top of the atmosphere in overcast conditions depends also on our knowledge of cloud properties, including their scattering phase function, tridimensional structure and top height.

But the introduction of radiative transfer simulations in the computation of the cloud index also enhances the importance of an accurate calibration of satellite radiance measurements. Using the gain coefficients developed by Doelling et al. (2018) for CERES-SYN1deg instead of EUMETSAT operational coefficients is sufficient to remove most of the mean bias observed between simulations and measurements of reflectances at the top of the atmosphere in clear-sky conditions, for the channel $0.6 \mu \mathrm{m}$. Besides, this increases the mean bias for the $0.8 \mu \mathrm{m}$. It is possibly due to a weaker compensation of the errors on the calibration and caused by the linear spectral interpolation applied between MODIS channels to reproduce reflexion properties of vegetated surfaces.

The simple relationship between the cloud index and the clear-sky index used here explains the significant amount of negative values of DSSI estimates. The improvement of this relation will be the object of a future study.

Finally, the quality of the results depends also on the quality of the clear-sky surface irradiance model : the example of the McClear model shows typical biases of $3 \%$ for the studied stations, when compared to BSRN irradiance data (Fig. C1). The improvement towards a least biased estimation of the downwelling surface solar irradiance based on a cloud index will require better estimates of the attenuation of the solar radiation by the clear atmosphere.

\section{Conclusion and perspectives}

A method to compute the cloud index is described in the framework of the development of the future Heliosat-V method for estimating downwelling surface solar irradiance from satellite imagery. The cloud index is built to deal with a single radiometric channel in the spectral range 400-1000 nm. It also does not need archives of data to quantify the cloud effective transmissivity. This approach has advantages. First, the concept of the Heliosat-V cloud index enables the use of imagery from geostationary and non-geostationary platforms, an asset to reach an extended spatial coverage. Moreover, the approach has the potential to deal with long time series of imagery from radiometers characterized by different spectral sensitivities and viewing geometries.

Validation results using SEVIRI imagery show that DSSI can be estimated by a cloud index method that does not rely on archives of imagery, with a quality similar to operational satellite-based data products like CAMS Radiation Service and HelioClim3, in terms of RMSD and correlation. This is an encouraging step toward the application of a Heliosat method to 
non geostationary satellite sensors. However, we note that there are differentiated errors depending on the spectral channel considered. This could be attenuated notably by an external knowledge on cloud top height and by improving the spectral interpolation of reflexion properties of vegetated surfaces.

To clarify the potential of the method for long time series of imagery, we will need to explore how sensitive to the quality of input data the results are. The knowledge on atmospheric composition in absorbing and scattering species and on surface reflectivity properties is notably lower for past periods like 1980's than for today. Also, the absolute calibration of satellite imagery can be more uncertain, without on-orbit calibrated instruments. Many inputs of the method have very different degrees of quality, depending on the period considered: the composition of the clear-sky atmosphere (aerosols and gases), surface properties, external clear-sky irradiance model. Further work is still to be done on multidecadal time series to study how the quality of such ancillary data affect the estimates of DSSI.

Also, producing global maps of DSSI requires to deal with non geostationary satellite imagery. First tests of the method have been made on the imagery of the Earth Polychromatic Imaging Camera (EPIC) embedded on the DSCOVR platform. They show encouraging results that will be extended and detailed in a future publication.

345 Global coverage of DSSI information obviously requires also to deal with ocean surfaces and snow covered regions, and this will need to be treated in the future.

Code availability. Excerpts of code are available at https://cloud.mines-paristech.fr/index.php/s/HAWmw7Fs927EtME

Data availability. DSSI results derived from the implementation of Heliosat-V for validation on all 11 stations are available at https://cloud. mines-paristech.fr/index.php/s/HAWmw7Fs927EtME, along with simulated and MSG measured reflectances, cloud and clear-sky indices and clear-sky irradiance estimates from the McClear model. The manually filtered clear-sky instants are also provided for all 11 locations. 
https://doi.org/10.5194/amt-2020-480

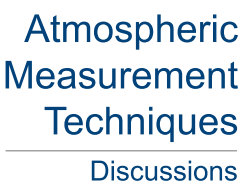

Preprint. Discussion started: 12 February 2021

(C) Author(s) 2021. CC BY 4.0 License.

(c) (i)

Discussions

\section{Appendix A: Methods}

\section{A1 Set-up of validation}
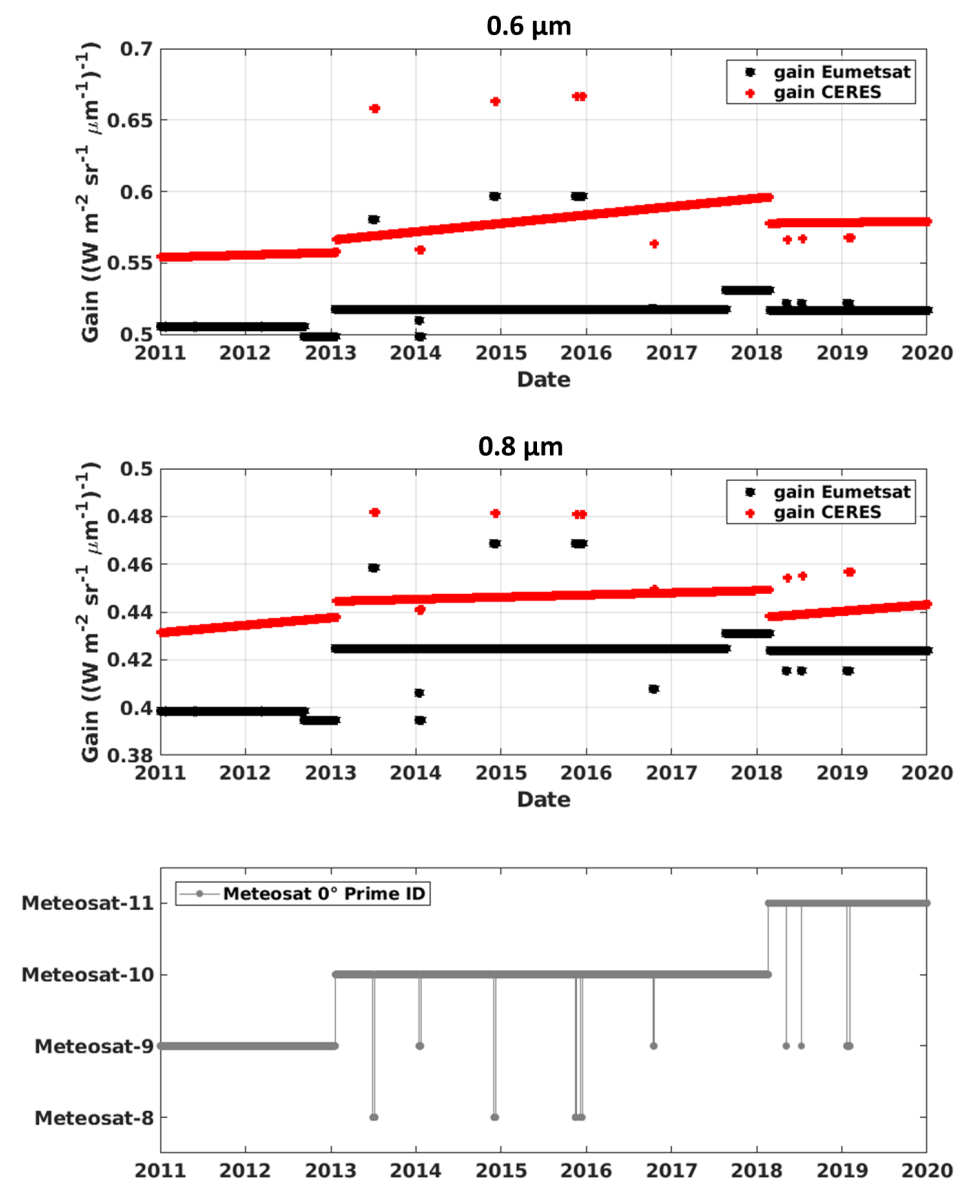

Figure A1. First two rows: calibration gains provided by EUMETSAT (black stars) and by CERES-SYN1deg (Doelling et al., 2018) (red stars) for $0.6 \mu \mathrm{m}$ channel (first row) and $0.8 \mu \mathrm{m}$ (second row) of SEVIRI sensor aboard Meteosat-9, between 2011 and 2019 . Third row: ID of the operational satellite at the longitude $0^{\circ}$. 
https://doi.org/10.5194/amt-2020-480

Preprint. Discussion started: 12 February 2021

(c) Author(s) 2021. CC BY 4.0 License.
Atmospheric Measurement

Techniques

\section{Appendix B: Results}

\section{B1 Simulated TOA clear-sky reflectances $\rho_{\text {clear }}$}
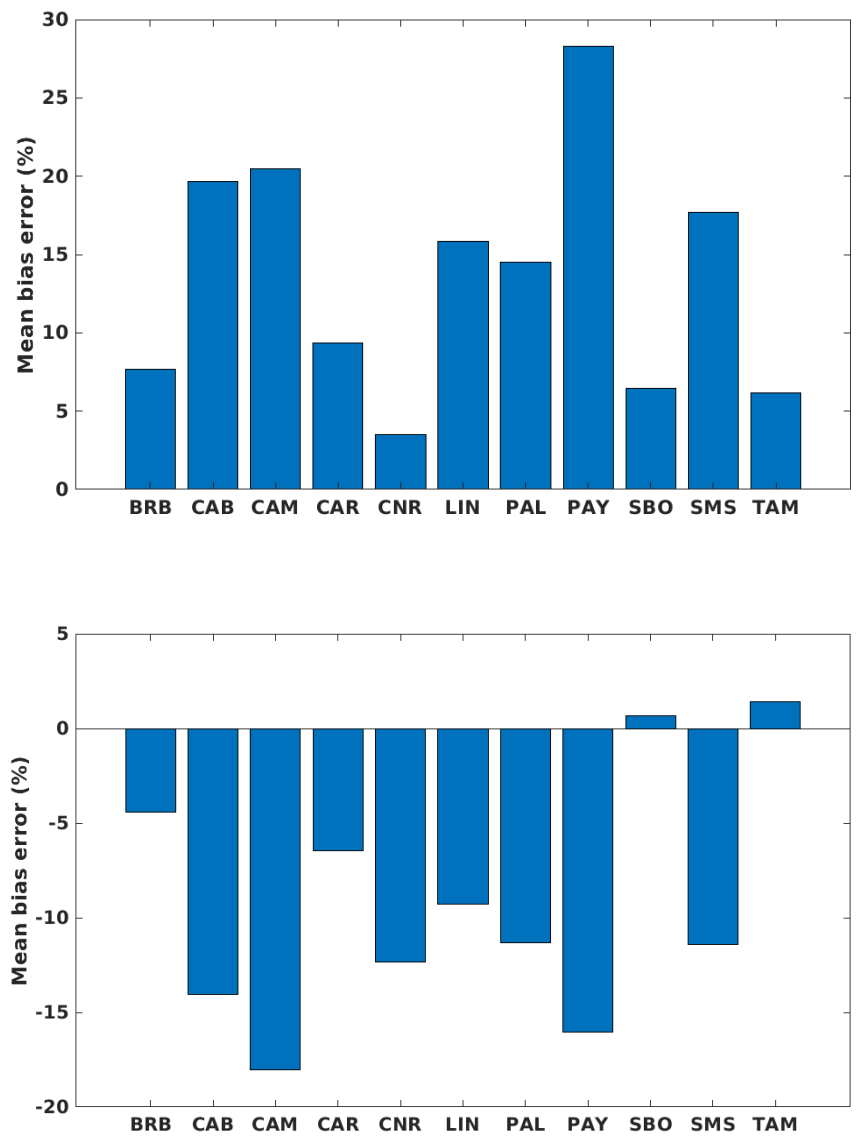

Figure B1. Relative mean bias errors of simulated clear-sky reflectances at the top of the atmosphere $\rho_{\text {clear }}$ ((simulationmeasurement)/measurement) for channels $0.6 \mu \mathrm{m}$ (upper panel) and $0.8 \mu \mathrm{m}$ (lower panel), and for each BSRN site. 
https://doi.org/10.5194/amt-2020-480

Atmospheric

Preprint. Discussion started: 12 February 2021

(c) Author(s) 2021. CC BY 4.0 License.
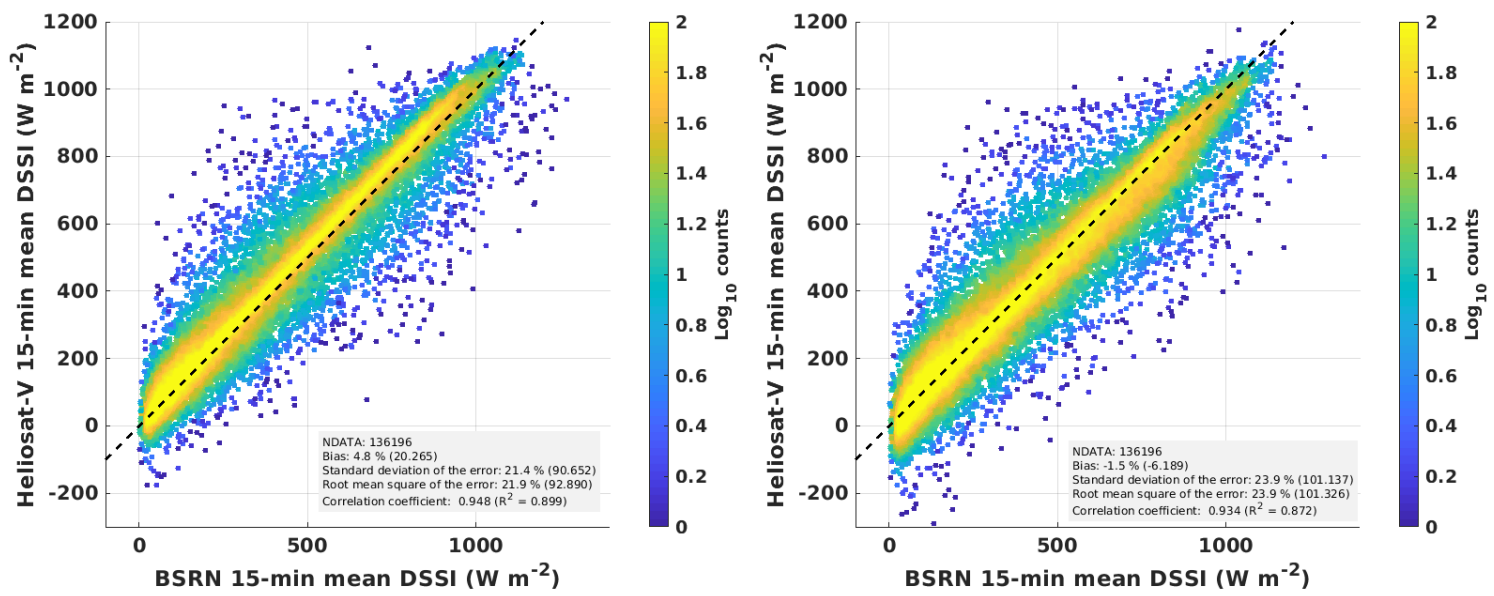

Figure B2. 2D-histograms of satellite-based DSSI estimates from the Heliosat-V method versus ground-based BSRN measurements for MSG $0.6 \mu \mathrm{m}$ channel (left panel) and $0.8 \mu \mathrm{m}$ channel (right panel). 
https://doi.org/10.5194/amt-2020-480

Preprint. Discussion started: 12 February 2021

(c) Author(s) 2021. CC BY 4.0 License.

(c) (i) $\begin{array}{r}\text { Atmospheric } \\ \text { Measurement } \\ \text { Techniques } \\ \hline \text { Discussions }\end{array}$

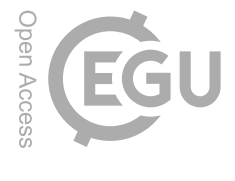

Table B1. Validation results for 15-min means of all-sky DSSI, for the year 2011. Results based on the imagery of Meteosat-9/SEVIRI 0.8 $\mu \mathrm{m}$ channel.

\begin{tabular}{c|c|c|c|c|c}
\hline Station & Number of samples & $\begin{array}{c}\text { Mean BSRN } \\
\mathrm{W} \mathrm{m}^{-2}\end{array}$ & $\begin{array}{c}\text { Bias } \\
\mathrm{W} \mathrm{m}^{-2}(\%)\end{array}$ & $\begin{array}{c}\text { RMSD } \\
\mathrm{W} \mathrm{m}^{-2}(\%)\end{array}$ & $\begin{array}{c}\text { Correlation coefficient } \\
(\mathrm{R})\end{array}$ \\
\hline Brasilia & 13570 & 504 & $13(3)$ & $142(28)$ & 0.871 \\
Cabauw & 13222 & 301 & $-27(-9)$ & $93(31)$ & 0.919 \\
Camborne & 12731 & 310 & $-28(-9)$ & $117(38)$ & 0.875 \\
Carpentras & 12642 & 452 & $19(4)$ & $81(18)$ & 0.958 \\
CENER & 14164 & 412 & $-9(-2)$ & $96(23)$ & 0.932 \\
Lindenberg & 13637 & 317 & $-18(-6)$ & $92(29)$ & 0.920 \\
Palaiseau & 13993 & 335 & $-14(4)$ & $88(26)$ & 0.934 \\
Payerne & 9191 & 387 & $-22(-6)$ & $99(26)$ & 0.936 \\
Sede Boker & 13574 & 589 & $23(4)$ & $91(16)$ & 0.947 \\
Sao Martinho da Serra & 5864 & 501 & $-49(-10)$ & $124(25)$ & 0.918 \\
Tamanrasset & 13609 & 579 & $15(3)$ & $89(15)$ & 0.954 \\
\hline Total & 136197 & 424 & $-6(-2)$ & $101(24)$ & 0.934
\end{tabular}


https://doi.org/10.5194/amt-2020-480

Preprint. Discussion started: 12 February 2021

(c) Author(s) 2021. CC BY 4.0 License.

(c) (1)

\section{Atmospheric Measurement Techniques \\ Discussions}

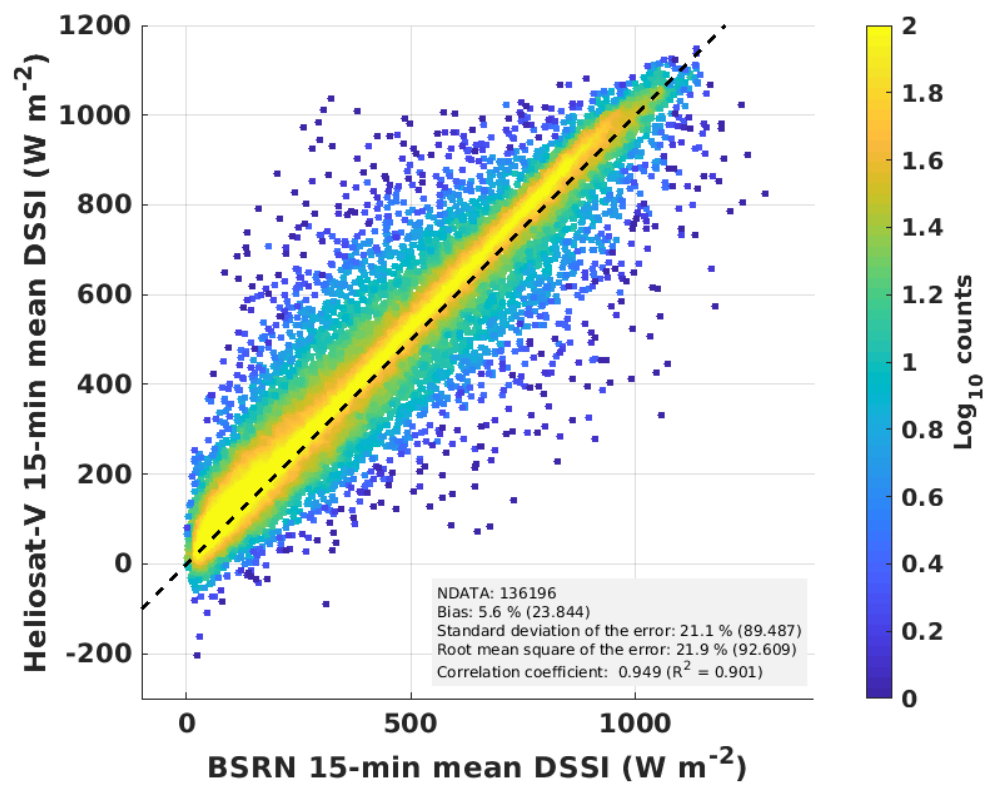

Figure B3. Impact of cloud phase on DSSI estimates. 2D-histogram of satellite-based DSSI estimates from the Heliosat-V method versus ground-based BSRN measurements for the MSG $0.6 \mu \mathrm{m}$ channel. The liquid cloud look-up table of overcast-sky TOA reflectances is replaced for the ice cloud LUT. 
https://doi.org/10.5194/amt-2020-480

Preprint. Discussion started: 12 February 2021

(C) Author(s) 2021. CC BY 4.0 License.

(c) (i)
Atmospheric Measurement Techniques

Discussions

\section{Appendix C: Discussion}

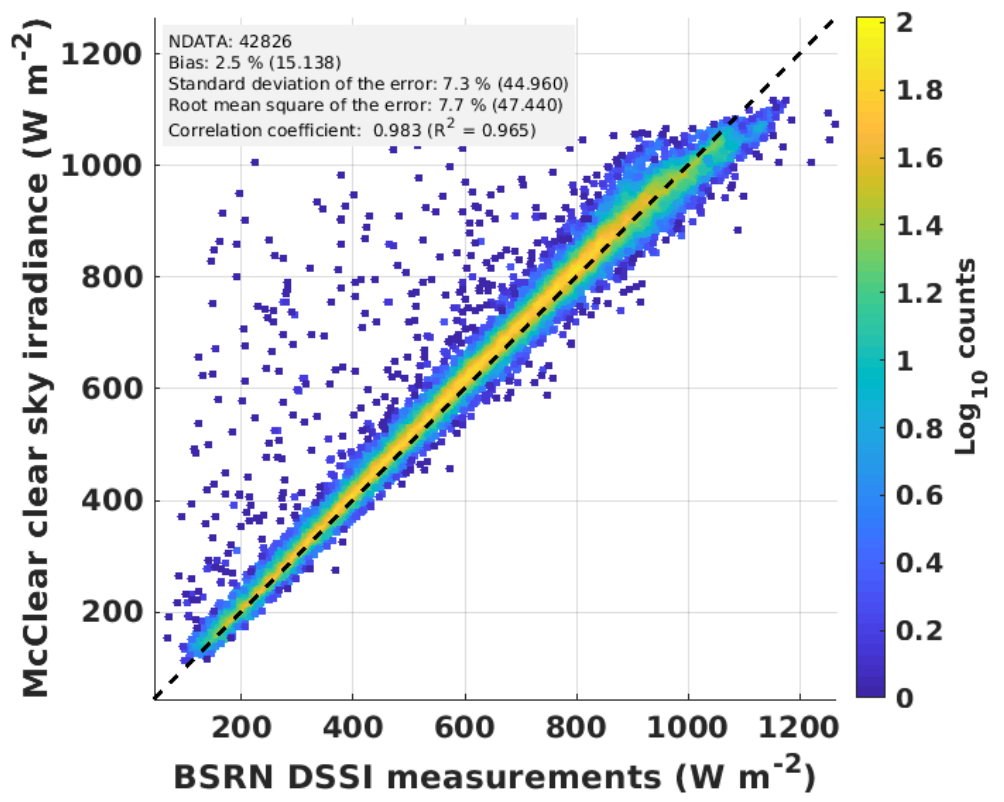

Figure C1. 2D histogram of 15-min mean clear-sky DSSI from the McClear model versus BSRN measurements from the 11 locations and year 2011. Cloudy instants filtered out with the mask used for Fig. 6. 
https://doi.org/10.5194/amt-2020-480

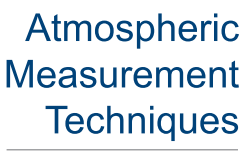

(c) Author(s) 2021. CC BY 4.0 License.

(c) (1)

Discussions

Author contributions. Conceptualization by BT, YMSD and PB. Investigation, validation and writing -original draft by BT. Visualization by BT and PB. BT and BG did software, with contributions from PB. Supervision by PB and BG. Methodology by BT, PB and YMSD. All authors brought contributions in the writing process.

360 Competing interests. BT is funded by Region Sud and the company Transvalor for his PhD work.

Acknowledgements. We would like to thank operators of the BSRN stations for producing and providing precious validation measurements. We are grateful to the libRadtran team for their open radiative transfer model and interactions. The MODIS MCD43C1 version 6 data product was retrieved from the online NASA Earthdata Search, courtesy of the NASA EOSDIS Land Processes Distributed Active Archive Center (LP DAAC), USGS/Earth Resources Observation and Science (EROS) Center, Sioux Falls, South Dakota, https://search.earthdata.nasa.gov/.

365 We also acknowledge EUMETSAT and the ECMWF for providing respectively Meteosat-9 and MACC reanalysis aerosol, water vapour and ozone data. We finally acknowledge Olivier Boucher, Alba Lorente, François-Marie Bréon, Jérome Vidot, Nicolas Ferlay, Philippe Dubuisson, Maximilien Patou, Alexander Marshak, Alexei Lyapustin, Jay Herman, Yuekui Yang, Tamas Varnai, Richard Perez, Paul Stackhouse, Seiji Kato, David Doelling and Bastiaan Van Diedenhoven for useful discussions. 
https://doi.org/10.5194/amt-2020-480

Preprint. Discussion started: 12 February 2021

(c) Author(s) 2021. CC BY 4.0 License.
Atmospheric

Measurement

Techniques

Discussions

\section{References}

Amarasinghe, N., Platnick, S., and Meyer, K.: Overview of the MODIS Collection 6 Cloud Optical Property (MOD06) Retrieval Look-up Tables, NASA GSFC Cloud Retrieval Product Team, 2017.

Anderson, G., Clough, S., Kneizys, F., Chetwynd, J., and Shettle, E.: AFGL Atmospheric Constituent Profiles (0.120km), p. 46, 1986.

Beyer, H. G., Costanzo, C., and Heinemann, D.: Modifications of the Heliosat procedure for irradiance estimates from satellite images, Solar Energy, 56, 207-212, https://doi.org/https://doi.org/10.1016/0038-092X(95)00092-6, 1996.

Blanc, P. and Wald, L.: The SG2 algorithm for a fast and accurate computation of the position of the Sun for multi-decadal time period, Solar Energy, 86, 3072-3083, https://doi.org/10.1016/j.solener.2012.07.018, 2012.

Buras, R., Dowling, T., and Emde, C.: New secondary-scattering correction in DISORT with increased efficiency for forward scattering, Journal of Quantitative Spectroscopy and Radiative Transfer, 112, 2028-2034, https://doi.org/10.1016/j.jqsrt.2011.03.019, 2011.

Cano, D.: Etude de l'ennuagement par analyse de séquences d'images de satellite: application à l'évaluation du rayonnement solaire global au sol, Thèse de doctorat, Ecole Nationale Supérieure des Mines de Paris, 1982.

Cano, D., Monget, J., Albuisson, M., Guillard, H., Regas, N., and Wald, L.: A method for the determination of the global solar radiation from meteorological satellite data, Solar Energy, 37, 31-39, https://doi.org/10.1016/0038-092X(86)90104-0, 1986.

Cox, S. J., Stackhouse, P. W., Gupta, S. K., Mikovitz, J. C., and Zhang, T.: NASA/GEWEX shortwave surface radiation budget: Integrated data product with reprocessed radiance, cloud, and meteorology inputs, and new surface albedo treatment, AIP Conference Proceedings, 1810, 090001 , https://doi.org/10.1063/1.4975541, 2017.

Darnell, W. L., Staylor, W. F., Gupta, S. K., and Denn, F. M.: Estimation of Surface Insolation Using Sun-Synchronous Satellite Data, Journal of Climate, 1, 820-835, https://doi.org/10.1175/1520-0442(1988)001<0820:EOSIUS>2.0.CO;2, 1988.

Dave, J. V.: Effect of Aerosols on the Estimation of Total Ozone in an Atmospheric Column from the Measurements of Its Ultraviolet Radiance, Journal of the Atmospheric Sciences, 35, 899-911, https://doi.org/10.1175/1520-0469(1978)035<0899:EOAOTE>2.0.CO;2, 1978.

Doelling, D., Haney, C., Bhatt, R., Scarino, B., and Gopalan, A.: Geostationary Visible Imager Calibration for the CERES SYN1deg Edition 4 Product, Remote Sensing, 10, 288, https://doi.org/10.3390/rs10020288, 2018.

Driemel, A., Augustine, J., Behrens, K., Colle, S., Cox, C., Cuevas-Agulló, E., Denn, F. M., Duprat, T., Fukuda, M., Grobe, H., Haeffelin, M., Hodges, G., Hyett, N., Ijima, O., Kallis, A., Knap, W., Kustov, V., Long, C. N., Longenecker, D., Lupi, A., Maturilli, M., Mimouni, M., Ntsangwane, L., Ogihara, H., Olano, X., Olefs, M., Omori, M., Passamani, L., Pereira, E. B., Schmithüsen, H., Schumacher, S., Sieger, R., Tamlyn, J., Vogt, R., Vuilleumier, L., Xia, X., Ohmura, A., and König-Langlo, G.: Baseline Surface Radiation Network (BSRN): structure and data description (1992-2017), Earth System Science Data, 10, 1491-1501, https://doi.org/10.5194/essd-10-1491-2018, 2018.

Emde, C., Buras-Schnell, R., Kylling, A., Mayer, B., Gasteiger, J., Hamann, U., Kylling, J., Richter, B., Pause, C., Dowling, T., and Bugliaro, L.: The libRadtran software package for radiative transfer calculations (version 2.0.1), Geoscientific Model Development, 9, 1647-1672, https://doi.org/10.5194/gmd-9-1647-2016, 2016.

Gasteiger, J., Emde, C., Mayer, B., Buras, R., Buehler, S., and Lemke, O.: Representative wavelengths absorption parameterization applied to satellite channels and spectral bands, Journal of Quantitative Spectroscopy and Radiative Transfer, 148, 99-115, https://doi.org/10.1016/j.jqsrt.2014.06.024, 2014.

GCOS: The Global Observing System for Climate: Implementation Needs, Tech. Rep. GCOS-200 (GOOS-2014), Global Climate Observing System, https://doi.org/10.13140/RG.2.2.23178.26566, 2016. 
https://doi.org/10.5194/amt-2020-480

Preprint. Discussion started: 12 February 2021

(c) Author(s) 2021. CC BY 4.0 License.
Atmospheric

Measurement

Techniques

Discussions

Gelaro, R., McCarty, W., Suarez, M. J., Todling, R., Molod, A., Takacs, L., Randles, C. A., Darmenov, A., Bosilovich, M. G., Reichle, R., Wargan, K., Coy, L., Cullather, R., Draper, C., Akella, S., Buchard, V., Conaty, A., da Silva, A. M., Gu, W., Kim, G.-K., Koster, R., Lucchesi, R., Merkova, D., Nielsen, J. E., Partyka, G., Pawson, S., Putman, W., Rienecker, M., Schubert, S. D., Sienkiewicz, M., and Zhao, B.: The Modern-Era Retrospective Analysis for Research and Applications, Version 2 (MERRA-2), Journal of Climate, 30, 5419-5454, https://doi.org/10.1175/JCLI-D-16-0758.1, 2017.

Gschwind, B., Wald, L., Blanc, P., Lefevre, M., Schroedter-Homscheidt, M., and Arola, A.: Improving the McClear model estimating the downwelling solar radiation at ground level in cloud-free conditions - McClear-v3, Meteorologische Zeitschrift, 28, 147-163, https://doi.org/10.1127/metz/2019/0946, 2019.

Gueymard, C. A.: Revised composite extraterrestrial spectrum based on recent solar irradiance observations, Solar Energy, 169, 434-440, https://doi.org/10.1016/j.solener.2018.04.067, 2018.

Gupta, S. K., Kratz, D. P., Stackhouse Jr, P. W., and Wilber, A. C.: The Langley Parameterized Shortwave Algorithm (LPSA) for Surface Radiation Budget Studies. 1.0, NASA/TP-2001-211272, 2001.

Hao, D., Asrar, G. R., Zeng, Y., Zhu, Q., Wen, J., Xiao, Q., and Chen, M.: Estimating hourly land surface downward shortwave and photosynthetically active radiation from DSCOVR/EPIC observations, Remote Sensing of Environment, 232, 111320, https://doi.org/10.1016/j.rse.2019.111320, 2019.

Hao, D., Asrar, G. R., Zeng, Y., Zhu, Q., Wen, J., Xiao, Q., and Chen, M.: DSCOVR/EPIC-derived global hourly/daily downward shortwave and photosynthetically active radiation data at $0.1^{\circ} \times 0.1^{\circ}$ resolution, Earth System Science Data Discussions, 2020, $1-16$, https://doi.org/10.5194/essd-2020-19, 2020.

Herman, J., Huang, L., McPeters, R., Ziemke, J., Cede, A., and Blank, K.: Synoptic ozone, cloud reflectivity, and erythemal irradiance from sunrise to sunset for the whole earth as viewed by the DSCOVR spacecraft from the earth-sun Lagrange 1 orbit, Atmospheric Measurement Techniques, 11, 177-194, https://doi.org/10.5194/amt-11-177-2018, 2018.

Hersbach, H., Bell, B., Berrisford, P., Hirahara, S., Horányi, A., Muñoz-Sabater, J., Nicolas, J., Peubey, C., Radu, R., Schepers, D., Simmons, A., Soci, C., Abdalla, S., Abellan, X., Balsamo, G., Bechtold, P., Biavati, G., Bidlot, J., Bonavita, M., De Chiara, G., Dahlgren, P., Dee, D., Diamantakis, M., Dragani, R., Flemming, J., Forbes, R., Fuentes, M., Geer, A., Haimberger, L., Healy, S., Hogan, R. J., Hólm, E., Janisková, M., Keeley, S., Laloyaux, P., Lopez, P., Lupu, C., Radnoti, G., de Rosnay, P., Rozum, I., Vamborg, F., Villaume, S., and Thépaut, J.: The ERA5 global reanalysis, Quarterly Journal of the Royal Meteorological Society, pp. 1-51, https://doi.org/10.1002/qj.3803, 2020.

Hess, M., Koepke, P., and Schult, I.: Optical properties of aerosols and clouds: The software package OPAC, Bulletin of the American meteorological society, 79, 831-844, https://doi.org/10.1175/1520-0477(1998)079<0831:OPOAAC>2.0.CO;2, 1998.

Huang, G., Li, Z., Li, X., Liang, S., Yang, K., Wang, D., and Zhang, Y.: Estimating surface solar irradiance from satellites: Past, present, and future perspectives, Remote Sensing of Environment, 233, 111371, https://doi.org/10.1016/j.rse.2019.111371, 2019.

Inness, A., Baier, F., Benedetti, A., Bouarar, I., Chabrillat, S., Clark, H., Clerbaux, C., Coheur, P., Engelen, R. J., Errera, Q., Flemming, J., George, M., Granier, C., Hadji-Lazaro, J., Huijnen, V., Hurtmans, D., Jones, L., Kaiser, J. W., Kapsomenakis, J., Lefever, K., Leitao, J., Razinger, M., Richter, A., Schultz, M. G., Simmons, A. J., Suttie, M., Stein, O., Thépaut, J.-N., Thouret, V., Vrekoussis, M., Zerefos, C., and the MACC team: The MACC reanalysis: an $8 \mathrm{yr}$ data set of atmospheric composition, Atmospheric Chemistry and Physics, 13 , 4073-4109, https://doi.org/10.5194/acp-13-4073-2013, 2013.

Jin, Z., Wielicki, B. A., Loukachine, C., Charlock, T. P., Young, D., and Noël, S.: Spectral kernel approach to study radiative response of climate variables and interannual variability of reflected solar spectrum, Journal of Geophysical Research: Atmospheres, 116, https://doi.org/10.1029/2010JD015228, 2011. 
https://doi.org/10.5194/amt-2020-480

Preprint. Discussion started: 12 February 2021

(c) Author(s) 2021. CC BY 4.0 License.
Atmospheric

Measurement

Techniques

Discussions

Kurucz, R. L.: Synthetic infrared spectra, in: Proceedings of the 154th Symposium of the International Astronomical Union (IAU), 154, pp. 523-531, Tucson, Arizona, March 2-6, 1992, Kluwer, Acad., Norwell, MA, 1992.

Lefèvre, M., Wald, L., and Diabaté, L.: Using reduced data sets ISCCP-B2 from the Meteosat satellites to assess surface solar irradiance, Solar Energy, 81, 240-253, https://doi.org/10.1016/j.solener.2006.03.008, https://doi.org/10.1016\%2Fj.solener.2006.03.008, 2007.

Lefèvre, M., Oumbe, A., Blanc, P., Espinar, B., Gschwind, B., Qu, Z., Wald, L., Homscheidt, M. S., Hoyer-Klick, C., and Arola, A.: McClear: a new model estimating downwelling solar radiation at ground level in clear-sky conditions, Atmospheric Measurement Techniques, 6 , 2403-2418, https://doi.org/10.5194/amt-6-2403-2013, 2013.

Long, C. N. and Turner, D. D.: A method for continuous estimation of clear-sky downwelling longwave radiative flux developed using ARM surface measurements, Journal of Geophysical Research: Atmospheres, 113, https://doi.org/10.1029/2008JD009936, 2008.

Lorente, A., Boersma, K. F., Stammes, P., Tilstra, L. G., Richter, A., Yu, H., Kharbouche, S., and Muller, J.-P.: The importance of surface reflectance anisotropy for cloud and $\mathrm{NO}_{2}$ retrievals from GOME-2 and OMI, Atmospheric Measurement Techniques, 11, 4509-4529, https://doi.org/10.5194/amt-11-4509-2018, 2018.

Lucht, W., Schaaf, C. B., and Strahler, A. H.: An algorithm for the retrieval of albedo from space using semiempirical BRDF models, IEEE Transactions on Geoscience and Remote Sensing, 38, 977-998, https://doi.org/10.1109/36.841980, 2000.

Lyapustin, A., Wang, Y., Korkin, S., and Huang, D.: MODIS Collection 6 MAIAC algorithm, Atmospheric Measurement Techniques, 11, 5741-5765, https://doi.org/10.5194/amt-11-5741-2018, 2018.

460 Marshak, A., Herman, J., Szabo, A., Blank, K., Carn, S., Cede, A., Geogdzhayev, I., Huang, D., Huang, L.-K., Knyazikhin, Y., Kowalewski, M., Krotkov, N., Lyapustin, A., McPeters, R., Meyer, K. G., Torres, O., and Yang, Y.: Earth Observations from DSCOVR EPIC Instrument, Bulletin of the American Meteorological Society, 99, 1829-1850, https://doi.org/10.1175/BAMS-D-17-0223.1, 2018.

Mayer, B., Kylling, A., Emde, C., Buras, R., Hamann, U., Gasteiger, J., and Richter, B.: libRadtran user's guide, Edition for libRadtran version 2.0.2, 2017.

Mueller, R., Matsoukas, C., Gratzki, A., Behr, H., and Hollmann, R.: The CM-SAF operational scheme for the satellite based retrieval of solar surface irradiance - A LUT based eigenvector hybrid approach, Remote Sensing of Environment, 113, 1012-1024, https://doi.org/10.1016/j.rse.2009.01.012, 2009.

Möser, W. and Raschke, E.: Mapping of global radiation and cloudiness from Meteosat image data - Theory and ground truth comparisons, Meteorologische Rundschau, 36, 33-41, 1983.

Möser, W. and Raschke, E.: Incident Solar Radiation over Europe Estimated from METEOSAT Data, Journal of Climate and Applied Meteorology, 23, 166-170, https://doi.org/10.1175/1520-0450(1984)023<0166:ISROEE>2.0.CO;2, 1984.

Ohmura, A., Dutton, E. G., Forgan, B., Fröhlich, C., Gilgen, H., Hegner, H., Heimo, A., König-Langlo, G., McArthur, B., Müller, G., Philipona, R., Pinker, R., Whitlock, C. H., Dehne, K., and Wild, M.: Baseline Surface Radiation Network (BSRN/WCRP): new precision radiometry for climate research, Bulletin of the American Meteorological Society, 79, 2115-2136, https://doi.org/10.1175/15200477(1998)079<2115:BSRNBW>2.0.CO;2, 1998.

Perez, R., Ineichen, P., Moore, K., Kmiecik, M., Chain, C., George, R., and Vignola, F.: A new operational model for satellite-derived irradiances: description and validation, Solar Energy, 73, 307-317, https://doi.org/https://doi.org/10.1016/S0038-092X(02)00122-6, 2002.

Pfeifroth, U., Kothe, S., Müller, R., Trentmann, J., Hollmann, R., Fuchs, P., and Werscheck, M.: Surface Radiation Data Set - Heliosat (SARAH) - Edition 2, Satellite Application Facility on Climate Monitoring, Satellite Application Facility on Climate Monitoring (CM SAF), https://doi.org/10.5676/EUM_SAF_CM/SARAH/V002, 2017. 
https://doi.org/10.5194/amt-2020-480

Preprint. Discussion started: 12 February 2021

(c) Author(s) 2021. CC BY 4.0 License.
Atmospheric

Measurement

Techniques

Discussions

Pinker, R. and Laszlo, I.: Modeling surface solar irradiance for satellite applications on a global scale, Joural of applied meteorology, 31, 194-211, https://doi.org/10.1175/1520-0450(1992)031<0194:MSSIFS>2.0.CO;2, 1992.

Qu, Z., Gschwind, B., Lefevre, M., and Wald, L.: Improving HelioClim-3 estimates of surface solar irradiance using the Mc-

Clear clear-sky model and recent advances in atmosphere composition, Atmospheric Measurement Techniques, 7, 3927-3933, https://doi.org/10.5194/amt-7-3927-2014, 2014.

Qu, Z., Oumbe, A., Blanc, P., Espinar, B., Gesell, G., Gschwind, B., Klüser, L., Lefèvre, M., Saboret, L., Schroedter-Homscheidt, M., and Wald, L.: Fast radiative transfer parameterisation for assessing the surface solar irradiance: The Heliosat-4 method, Meteorologische Zeitschrift, 26, 33-57, https://doi.org/10.1127/metz/2016/0781, 2017.

Rigollier, C. and Wald, L.: Using Meteosat images to map the solar radiation: improvements of the HELIOSAT method, in: 9th Conference on Satellite Meteorology and Oceanography, vol. EUM-P-22, pp. 432-433, American Meteorological Society Ed., Boston, Massachusetts, USA, Paris, France, iSSN 1011-3932, 1998.

Rigollier, C., Lefèvre, M., and Wald, L.: The method Heliosat-2 for deriving shortwave solar radiation from satellite images, Solar Energy, 77, 159-169, https://doi.org/10.1016/j.solener.2004.04.017, 2004.

Roujean, J.-L., Leroy, M., and Deschamps, P.-Y.: A bidirectional reflectance model of the Earth's surface for the correction of remote sensing data, Journal of Geophysical Research: Atmospheres, 97, 20 455-20 468, 1992.

Schaaf, C. B., Gao, F., Strahler, A. H., Lucht, W., Li, X., Tsang, T., Strugnell, N. C., Zhang, X., Jin, Y., Muller, J.-P., Lewis, P., Barnsley, M., Hobson, P., Disney, M., Roberts, G., Dunderdale, M., Doll, C., d'Entremont, R. P., Hu, B., Liang, S., Privette, J. L., and Roy, D.: First operational BRDF, albedo nadir reflectance products from MODIS, Remote Sensing of Environment, 83, 135-148, https://doi.org/https://doi.org/10.1016/S0034-4257(02)00091-3, 2002.

Sengupta, M., Habte, A., Gueymard, C., Wilbert, S., and Renné, D.: Best Practices Handbook for the Collection and Use of Solar Resource Data for Solar Energy Applications: Second Edition, Tech. Rep. NREL/TP-5D00-68886, National Renewable Energy Laboratory, 2017.

Shettle, E.: Models of aerosols, clouds, and precipitation for atmospheric propagation studies, AGARD Conf. Proce., 1990.

Stammes, P., Sneep, M., de Haan, J. F., Veefkind, J. P., Wang, P., and Levelt, P. F.: Effective cloud fractions from the Ozone Monitoring Instrument: Theoretical framework and validation, Journal of Geophysical Research, 113, https://doi.org/10.1029/2007JD008820, 2008.

Stengel, M., Stapelberg, S., Sus, O., Finkensieper, S., Würzler, B., Philipp, D., Hollmann, R., Poulsen, C., Christensen, M., and McGarragh, G.: Cloud_cci Advanced Very High Resolution Radiometer post meridiem (AVHRR-PM) dataset version 3: 35-year climatology of global cloud and radiation properties, Earth System Science Data, 12, 41-60, https://doi.org/10.5194/essd-12-41-2020, 2020.

Stephens, G. L., Gabriel, P. M., and Partain, P. T.: Parameterization of atmospheric radiative transfer. Part I: Validity of simple models, Journal of the atmospheric sciences, 58, 3391-3409, https://doi.org/10.1175/1520-0469(2001)058<3391:POARTP>2.0.CO;2, 2001.

Stöckli, R.: The HelioMont Surface Solar Radiation Processing, Tech. Rep. 93, MeteoSwiss, 2014.

Tarpley, J.: Estimating incident solar radiation at the surface from geostationary satellite data, Journal of Applied Meteorology, 18, 11721181, https://doi.org/10.1175/1520-0450(1979)018<1172:EISRAT>2.0.CO;2, 1979.

Taylor, V. R. and Stowe, L.: Reflectance Characteristics of Uniform Earth and Cloud Surfaces Derived From NIMBUS-7 ERB, Journal of Geophysical Research, 89, 4987-4996, https://doi.org/10.1029/JD089iD04p04987, 1984.

515 Trishchenko, A. P., Li, Z., Chang, F.-L., and Barker, H.: Cloud optical depths and TOA fluxes: Comparison between satellite and surface retrievals from multiple platforms, Geophysical Research Letters, 28, 979-982, https://doi.org/10.1029/2000GL012067, 2001. 
Veefkind, J. P., de Haan, J. F., Sneep, M., and Levelt, P. F.: Improvements to the $\mathrm{OMI} \mathrm{O}_{2}-\mathrm{O}_{2}$ operational cloud algorithm and comparisons with ground-based radar-lidar observations, Atmospheric Measurement Techniques, 9, 6035-6049, https://doi.org/10.5194/amt-9-60352016, 2016.

Wang, P., Sneep, M., Veefkind, J., Stammes, P., and Levelt, P.: Evaluation of broadband surface solar irradiance derived from the Ozone Monitoring Instrument, Remote Sensing of Environment, 149, 88-99, 2014.

Wanner, W., Strahler, A., Hu, B., Lewis, P., Muller, J.-P., Li, X., Schaaf, C., and Barnsley, M.: Global retrieval of bidirectional reflectance and albedo over land from EOS MODIS and MISR data: Theory and algorithm, Journal of Geophysical Research D: Atmospheres, 102, 17 143-17 161, https://doi.org/10.1029/96JD03295, 1997.

WMO: World Meteorological Organization Guide to Meteorological Instruments and Methods of Observation (updated 2017), Chapter 7: Measurement of radiation, WMO, 2014.

Xie, Y., Sengupta, M., and Dudhia, J.: A Fast All-sky Radiation Model for Solar applications (FARMS): Algorithm and performance evaluation, Solar Energy, 135, 435-445, https://doi.org/10.1016/j.solener.2016.06.003, 2016.

Yang, P., Bi, L., Baum, B. A., Liou, K.-N., Kattawar, G. W., Mishchenko, M. I., and Cole, B.: Spectrally Consistent Scattering, Absorption, and Polarization Properties of Atmospheric Ice Crystals at Wavelengths from 0.2 to $100 \mu \mathrm{m}$, Journal of the Atmospheric Sciences, 70 , 330-347, https://doi.org/10.1175/JAS-D-12-039.1, 2013.

Zarzalejo, L. F., Polo, J., Martin, L., Ramirez, L., and Espinar, B.: A new statistical approach for deriving global solar radiation from satellite images, Solar Energy, 83, 480-484, https://doi.org/10.1016/j.solener.2008.09.006, 2009.

Zhang, H., Huang, C., Yu, S., Li, L., Xin, X., and Liu, Q.: A Lookup-Table-Based Approach to Estimating Surface Solar Irradiance from Geostationary and Polar-Orbiting Satellite Data, Remote Sensing, 10, 411, https://doi.org/10.3390/rs10030411, 2018.

Zhang, Y.: Calculation of radiative fluxes from the surface to top of atmosphere based on ISCCP and other global data sets: Refinements of the radiative transfer model and the input data, Journal of Geophysical Research, 109, https://doi.org/10.1029/2003JD004457, 2004. 